Biogeosciences Discuss., https://doi.org/10.5194/bg-2017-453

Manuscript under review for journal Biogeosciences

Discussion started: 2 November 2017

(c) Author(s) 2017. CC BY 4.0 License.

\title{
Effects of the interaction of ocean acidification, solar radiation, and warming on biogenic dimethylated sulfur compounds cycling in the Changjiang River Estuary
}

Shan Jian ${ }^{1}$, Jing Zhang ${ }^{1,3}$, Hong-Hai Zhang ${ }^{1,3}$, and Gui-Peng Yang ${ }^{1,2,3}$

$5 \quad{ }^{1}$ Key Laboratory of Marine Chemistry Theory and Technology, Ocean University of China, Ministry of Education, Qingdao 266100, China

${ }^{2}$ Laboratory for Marine Ecology and Environmental Science, Qingdao National Laboratory for Marine Science and Technology, Qingdao 266071, China

${ }^{3}$ Institute of Marine Chemistry, Ocean University of China, Qingdao 266100, China

10 Correspondence to: Gui-Peng Yang (gpyang@ouc.edu.cn)

Abstract. Ocean acidification (OA) affects marine primary productivity and community structure, and therefore may influence the biogeochemical cycles of volatile biogenic dimethyl sulfide (DMS) and its precursor dimethylsulfoniopropionate (DMSP) and photochemical oxidation product dimethyl sulfoxide (DMSO). A 23-day incubation experiment on board was conducted to investigate the short-term response of biogenic sulfur compounds

15 production and cycling to $\mathrm{OA}$ in the Changiiang River Estuary and further understand its effects on biogenic sulfur compounds. Result showed that phytoplankton abundance and species presented remarkable differences under three different $\mathrm{pH}$ levels in the late stage of the experiment. A significant reduction in chlorophyll $a$ (Chl- $a$ ), DMS, particulate DMSP (DMSPp), and dissolved DMSO (DMSOd) concentrations was identified under high $\mathrm{CO}_{2}$ levels. Moreover, minimal change was observed in the production of dissolved DMSP (DMSPd) and particulate DMSO (DMSOp) among treatments. The ratios of DMS, total DMSP (DMSPt), and total DMSO (DMSOt) to Chl- $a$ were also not affected by a change in pH. In addition, DMS and DMSOd were highly related to mean bacterial abundance under three pH levels. Additional incubation experiments on light and temperature showed that the influence of $\mathrm{pH}$ on productions of dimethylated sulfur compounds also depended on solar radiation and temperature conditions. DMS photodegradation rate increased with decreasing $\mathrm{pH}$ under full-spectrum natural light and UVB light. Thus, OA may lead to decreasing DMS concentrations in the surface seawater. Light and temperature conditions also play an important role in the production and cycling of biogenic sulfur compounds. Keywords: Dimethylated sulfur compounds, Ocean acidification, Solar radiation, Warming, Bacteria, Phytoplankton

\section{Introduction}

The current atmospheric $\mathrm{CO}_{2}$ concentration $\left(p \mathrm{CO}_{2}\right)$ is around $380 \mu \mathrm{atm}$ and rising at an unprecedented rate. According to the Special Report on Emissions Scenarios by the Intergovernmental Panel on Climate Change, $p \mathrm{CO}_{2}$ is predicted to reach approximately $1,000 \mu \mathrm{atm}$ by 2100 (Nakicenovic and Swart, 2000), thereby decreasing the surface ocean pH levels by $0.2-$ 
Biogeosciences Discuss., https://doi.org/10.5194/bg-2017-453

Manuscript under review for journal Biogeosciences

Discussion started: 2 November 2017

(c) Author(s) 2017. CC BY 4.0 License.

0.5 units (Caldeira and Wickett, 2003). The primary consequence of the inexorable increase in oceans' acidity is a change in seawater carbonate system and a decrease in the saturation state of calcite and aragonite carbonate. This change could affect marine ecological environment and primary productivity, as more $\mathrm{CO}_{2}$ (low $\mathrm{pH}$ ) will affect physiological process of marine organism (Fu et al., 2007; Mélancon et al., 2016; Orr et al., 2005). The oceans are an important source of some atmosphere 5 trace gases which affect atmospheric chemistry and global climate (Arnold et al., 2013; Asher et al., 2016; Park et al., 2014).

Dimethyl sulfide (DMS) is an important climatically active biogenic gas. It is produced by enzymatic cleavage of dimethylsulfoniopropionate (DMSP) (Gabric et al., 2010), which is synthesized by marine phytoplankton as a phytoplankton-derived precursor of DMS. DMS is the dominant volatile sulfur compound in ocean surface waters (Quinn and Bates, 2011) and its emissions from the ocean to the atmosphere corresponds to almost $90 \%$ of the marine biogenic

10 sulfur in the atmosphere (Wakeham, 1986). Once emitted to atmosphere, DMS undergoes rapid oxidation to produce particles which, through direct and indirect interactions with incoming solar radiation, affect planetary albedo (Barnes et al., 2006; Charlson et al., 1987; Rap et al., 2013). Shaw hypothesized that DMS and sulfate aerosols are linked to global climate. This link was further elaborated by Charlson et al. (1987). Consequently, ocean acidification (OA)-induced changes in the primary productivity might impact on the production rate and sea-to-air emission of DMS and these impacts might further

15 affect cloud formation and climate.

DMSP, as the main precursor of DMS, is produced by various phytoplankton species and presents an important effect on the biogeochemical cycle of climatically active trace gas DMS (Keller et al., 1989). DMSP is released from phytoplankton cells into the dissolved phase through active exudation or when cells are lysed during grazing (Wolfe et al., 2000), viral attack (Malin et al., 1998), or senescence (Stefels et al., 2007). The conversion of DMSP to DMS is controlled by a number

20 of chemical and biological processes (Archer et al., 2002). DMSP is degraded in seawater via two main pathways. DMSPlyase pathway contributes only a considerably small fraction to DMSP metabolism in seawater. The most preferred and dominant process is the dimethylation/demethiolation pathway, which diverts sulfur away from DMS production (Kiene and Bates, 1990). However, whether shifts in DMS yield occur under OA condition is unknown.

Dimethyl sulfoxide (DMSO) is the major nonvolatile dimethyl sulfur pool in seawater and also plays an important role in 25 biogeochemical cycle of DMS. Marine DMSO is derived mainly from DMS through abiotic photolysis and biological consumption (Brimblecombe and Shooter, 1986; Kieber et al., 1996; Toole and Siegel, 2004). DMSO was initially conceived as a sink for DMS. Nevertheless, DMSO was later found a potential source of DMS (Hatton et al., 2012). DMSO can be biologically reduced to DMS via enzymatic reactions that might depend on reductases (Spiese et al., 2009). Thus, DMSO is a key compound in the complex redox loop that is involved in marine sulfur cycle because it can be both an end

30 product of DMS oxidation and a precursor of DMS, which potentially plays an important role in climate regulation (Charlson et al., 1987; Deschaseaux et al., 2014).

Along with ocean acidification, global warming associated with the increasing atmospheric $\mathrm{CO}_{2}$ accumulation is leading to a greenhouse ocean, which is characterized by increased sea surface temperature and a shoaling of the upper mixed layer (Capotondi et al., 2012; Doney, 2006; Gao et al., 2012a; Hays et al., 2005). The declining stratospheric ozone over the globe 
Biogeosciences Discuss., https://doi.org/10.5194/bg-2017-453

Manuscript under review for journal Biogeosciences

Discussion started: 2 November 2017

(c) Author(s) 2017. CC BY 4.0 License.

and change in the upper mixed layer would enhance the levels of ultraviolet radiation (UVR) (280 to $400 \mathrm{~nm}$ ) reaching the sea surface. The ocean undergoes multiple environmental changes. Other climatic ecological stressor or factors would probably alter the effects of ocean acidification on the production and consumption process of DMS in both direct and indirect ways (Arnold et al., 2013). A recent study predicts that pH level can influence the photodegradation of DMS

5 (Bouillon and Miller, 2005). The photochemical process of DMS in the surface water would change due to the changing light level and seawater pH level. So these concomitant global change variables should be taken into consideration to better explain the effect of acidification on DMS.

The effects of simulated future $\mathrm{CO}_{2}$-induced seawater acidification on DMS production are still controversial (Avgoustidi et al., 2012; Kerrison et al., 2012; Kim et al., 2010; Vogt et al., 2008). Hence, we conducted a shipboard incubation

10 experiment in the Changjiang River Estuary to further investigate the OA effects in the cycling of marine DMS, DMSP, and DMSO under three $\mathrm{pH}$ treatments. Moreover, we examined the photolysis rate and concentration changes of DMS under the dual stressors of changing $\mathrm{pH}$ and solar radiation/temperature and assessed the coupling effects of OA, solar radiation and warming on biogenic dimethylated sulfur compounds cycling.

\section{Materials and methods}

\section{$15 \quad 2.1$ Experimental design}

Deck incubation experiment of ocean acidification was conducted aboard the R/V 'Run Jiang No. 1' in March 7-23, 2016 and continued for 5 days at the laboratory. The surface seawater $(5 \mathrm{~m})$ sample, encompassing a range of environmental conditions, was collected from the station A6-9 $\left(123.50^{\circ} \mathrm{E}, 30.56^{\circ} \mathrm{N}\right)$ in the Changjiang River Estuary using $20 \mathrm{~L}$ Niskin bottles mounted on a CTD rosette. Environmental conditions of the sampling station were measured by CTD. Initial

20 temperature and salinity were $12.33{ }^{\circ} \mathrm{C}$ and $33.79 \%$, respectively. Phytoplankton communities were grown in nine $20 \mathrm{~L}$

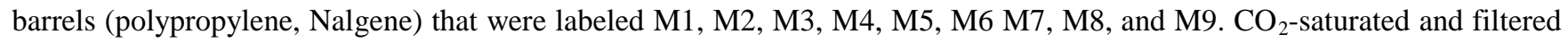
(0.2 $\mu \mathrm{m}$ of polyethersulfone membranes) seawater was gradually added to the nine incubation barrels until the target $\mathrm{pH}$ levels were reached on day 1 . The incubation experiment was initially equilibrated to the following conditions: (1) three were at ambient levels of $\mathrm{pH}(8.1, \mathrm{M} 1-\mathrm{M} 3$, LC group) without any subsequent processing step; (2) three were at medium

25 levels and expected at the end of this century (7.9, M4-M6, MC group), and (3) three were at relatively low pH levels as predicted for the middle of the next century (7.7, M7-M9, HC group). All treatments were exposed to sunlight in a flowthrough water bath to maintain treatments at their in situ temperature. Acidification incubation samples were gathered at 9:00 am daily or every second day. Additionally, three kinds of sulfur compounds (DMS, DMSP, and DMSO) and chlorophyll $a$ $(\mathrm{Chl}-a)$ samples were collected for analysis from day 1 to day 22. Seawater $\mathrm{pH}$ was continually measured using a pH meter

30 (S210 SevenCompact ${ }^{\mathrm{TM}}$, Mettler, Germany) and the precision is \pm 0.002 .

Incubations of filtered surface seawater with same DMS concentrations $\left(5 \mathrm{nmol} \mathrm{L}{ }^{-1}\right)$ were distributed into $150 \mathrm{~mL}$ quartz tubes and subsequently allocated into different spectral treatments to examine the combined effects of OA and solar radiation; 
Biogeosciences Discuss., https://doi.org/10.5194/bg-2017-453

Manuscript under review for journal Biogeosciences

Discussion started: 2 November 2017

(c) Author(s) 2017. CC BY 4.0 License.

the treatments were as follows: (1) quartz tubes (full-spectrum natural light), (2) Mylar-D-wrapped quartz tubes transmitting 60\%-80\% of UVA and small amount of UVB, (3) UF3 Plexiglas-enclosed quartz tubes attenuating essentially all UVA and UVB with $92 \%$ of visible light transmitted, (4) three layers of aluminum foil-wrapped quartz tubes (dark) evaluating the dark loss of DMS, and (5) UVB radiation (results for full-spectrum natural light minus those for UVB-filtered light) (Hatton,

5 2002). All samples were exposed to ambient solar radiation for $8 \mathrm{~h}$ and sampled every $2 \mathrm{~h}$. Temperature experiments were also carried out with unfiltered water in quartz bottle under in situ temperature at $12{ }^{\circ} \mathrm{C}$ and high temperature at $18{ }^{\circ} \mathrm{C}$ for $8 \mathrm{~h}$. The temperature was continuously controlled by circulating in situ seawater, hot water, and ice. The pH levels for solar radiation and temperature experiments were controlled with the same methods as previously described.

\subsection{Analytical procedures}

10 Triplicate DMS samples were measured immediately after collection with a cryogenic purge-and-trap preconcentration technique in accordance with the methods described by Zhang et al. (2008). In brief, 2 mL aliquot of the sample was collected into a glass bubbling chamber, stripped with high-purity nitrogen, trapped in a 1/16 Teflon tube, and immersed in liquid nitrogen. The trapped gases were desorbed with hot water $\left(>90^{\circ} \mathrm{C}\right)$ and then introduced into a gas chromatograph (GC, Shimadzu GC-2014) with a flame photometric detector for analysis. A $3 \mathrm{~m} \times 3 \mathrm{~mm}$ glass column packed with $10 \%$

15 DGES on Chromosorb W-AW-DMCS was used to separate sulfur gases at $70{ }^{\circ} \mathrm{C}$. The precision of the method was better than $5 \%$, and the detection limit was 0.1 pmol of DMS.

The samples for dissolved DMSP (DMSPd) were separated by gravity filtering with a Whatman GF/F filter. For DMSPd samples, $4 \mathrm{~mL}$ of sample was transferred to a vial containing $40 \mu \mathrm{L}$ of concentrated sulfuric acid and then sealed. For the total DMSP (DMSPt) samples, $100 \mu \mathrm{L}$ of $50 \%$ sulfuric acid was directly added to $10 \mathrm{~mL}$ of unfiltered seawater samples and

20 then sealed. Before measurement, $300 \mu \mathrm{L}$ of $10 \mathrm{~mol} \mathrm{~L}^{-1} \mathrm{KOH}$ was injected into $2 \mathrm{~mL}$ of preservative DMSP sample and incubated in the dark at $4{ }^{\circ} \mathrm{C}$ for at least $24 \mathrm{~h}$, thereby allowing the complete conversion of DMSP into DMS. Liberated DMS samples were determined using the above-mentioned methods.

The gravity-filtered samples for dissolved DMSO (DMSOd) were transferred to an immediately sealed vial that contained $20 \mu \mathrm{L}$ of $25 \%$ hydrochloric acid. Approximately $50 \mu \mathrm{L}$ of $25 \%$ hydrochloric acid was directly added to $10 \mathrm{~mL}$ of unfiltered

25 seawater for the total DMSO (DMSOt) samples for analysis. Prior to the analysis, the samples were purged with ultrapure $\mathrm{N}_{2}$

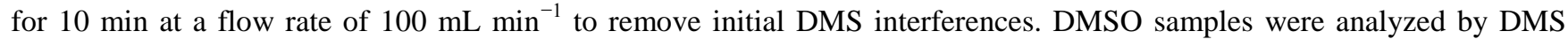
reduction with titanium trichloride at $55^{\circ} \mathrm{C}$ in the dark for $1 \mathrm{~h}$, in accordance with the procedures described by Kiene and Gerard (1994). The reduction of DMSO with TiCl3 can be expressed by the following reaction:

$\mathrm{C}_{2} \mathrm{H}_{6} \mathrm{SO}+2 \mathrm{TiCl}_{3}+2 \mathrm{HCl} \rightarrow \mathrm{C}_{2} \mathrm{H}_{6} \mathrm{~S}+2 \mathrm{Ti}(\mathrm{s})+4 \mathrm{Cl}_{2}(\mathrm{~g})+\mathrm{H}_{2} \mathrm{O}$

30 Chl- $a$ concentrations were measured with a Hitachi F-4500 fluorescence spectrophotometer after filtration of $300 \mathrm{~mL}$ of seawater sample with a Whatman GF/F glass fiber filter; subsequently, the sample was extracted in $90 \%$ acetone according to the methods described by Parsons et al. (1984). 
Biogeosciences Discuss., https://doi.org/10.5194/bg-2017-453

Manuscript under review for journal Biogeosciences

Discussion started: 2 November 2017

(c) Author(s) 2017. CC BY 4.0 License.

Approximately $200 \mathrm{~mL}$ of subsamples for phytoplankton analysis were fixed in neutralized formalin to a final concentration of $4 \%$ and concentrated to $10 \mathrm{~mL}$ by sedimentation. Phytoplankton species were identified and counted by microscopic examination under an inverted microscope (LEICA DRB) at magnifications of 400-600×.

Total bacterial abundances were measured using a LEICA DM5000B fluorescence spectrophotometer. Briefly, $20 \mathrm{~mL}$ of

5 seawater samples were preserved with formaldehyde (3.4\% final concentration) and kept in sterile $50 \mathrm{~mL}$ screw-cap plastic bottles in the dark at $4{ }^{\circ} \mathrm{C}$. To identify the bacteria, the samples were stained with 4',6-diamidino-2-phenylindole (a highly specific and sensitive fluorescing DNA stain) and counted by fluorescence microscopy according to the methods described by Porter and Feig (1980).

Total dissolved inorganic carbon (DIC) was determined by a DIC analyzer (AS-C2, Apollo SciTech Inc., Georgia, USA).

10 A sample of $0.5 \mathrm{~mL}$ was acidified by $0.5 \mathrm{~mL} 10 \%$ phosphoric acid and then the extracted $\mathrm{CO}_{2}$ gas was measured using a nondispersive infrared (NDIR) $\mathrm{CO}_{2}$ detector (LI-6262, Li-COR Inc., USA) with a precision of 0.1\%. The total alkalinity (TA) and $\mathrm{pCO}_{2}$ in sea water were calculated from DIC and $\mathrm{pH}$ using the CO2SYS (as refitted by Dickson and Millero (1987)).

\subsection{Statistical analyses}

Statistical analysis was performed using SPSS version 18.0 (SPSS Inc., IBM, USA). Pearson's correlation coefficient and

15 probability (p) were calculated to evaluate the quality of the fit when variables were normally distributed. T-test was used to determine whether a significant difference existed between two treatments. Variability in the concentrations of biogenic dimethylated sulfur compounds was analyzed using two-way ANOVA with $\mathrm{pH}$ and temperature/light as fixed factors and concentration as a random factor to understand whether an interaction existed between $\mathrm{pH}$ and temperature/light on concentration. Value at $\mathrm{p} \leq 0.05$ was considered statistically significant. Linear correlation analyses were used to determine the response of DMS, DMSO concentrations, and bacterial abundance to OA using Origin 9.1.

\section{Results}

\subsection{The effect of OA on Chl- $a$, DMS, DMSP and DMSO concentrations, and bacterial abundance}

\subsubsection{Variation in $\mathbf{p H}$}

At the start of the experiment, the seawater $\mathrm{pH}$ values in the incubation barrels were adjusted to the desired $\mathrm{pH}$ levels and the initial carbonate parameters are shown in Table 1. Seawater $\mathrm{pH}$ was adjusted with $\mathrm{CO}_{2}$-saturated seawater during the experiment to maintain a stable $\mathrm{pH}$ environment. In the first week, $\mathrm{pH}$ level was comparatively stable with a better control, but pH fluctuated obviously and was difficult to control in the stable and decline phases of algal growth. As shown in Fig. 1, the $\mathrm{pH}$ showed relatively apparent fluctuations on days 9-12 and days 18-20. This might be affected by multiple biological activities, in which the effect of microbial respiration should be the main influencing factor. $\mathrm{CO}_{2}$ emitted from microbial 
Biogeosciences Discuss., https://doi.org/10.5194/bg-2017-453

Manuscript under review for journal Biogeosciences

Discussion started: 2 November 2017

(c) Author(s) 2017. CC BY 4.0 License.

respiration can influence the carbonate balance system in seawater. Overall, the $\mathrm{pH}$ was controlled at relatively stable levels in the three treatments.

\subsubsection{Phytoplankton biomass and Chl-a}

Phytoplankton from station A6-9 included diatom, dinoflagellate, chrysophyceae, and cryptophyceae with a mean abundance

5 of 2135 cells $\mathrm{L}^{-1}$. Diatoms and dinoflagellates dominated the phytoplankton community, and their proportions were $67 \%$ and $32 \%$, respectively. The seawater samples of this station initially enclosed within incubation barrels exhibited a low-nutrient environment $\left(0.216 \mu \mathrm{mol} \mathrm{L}{ }^{-1} \mathrm{NO}_{3}^{-}, 0.0304 \mu \mathrm{mol} \mathrm{L}{ }^{-1} \mathrm{NO}_{2}^{-}, 0.963 \mu \mathrm{mol} \mathrm{L}{ }^{-1} \mathrm{NH}_{4}^{+}, 0.706 \mu \mathrm{mol} \mathrm{L}^{-1} \mathrm{PO}_{4}^{3-}\right.$, and $0.767 \mu \mathrm{mol}$ $\left.\mathrm{L}^{-1} \mathrm{SiO}_{3}{ }^{2-}\right)$ and low Chl- $a$ concentrations $\left(0.460 \mu \mathrm{g} \mathrm{L}^{-1}\right)$. Thus, in order to guarantee that phytoplankton biomass could be determined during incubations, nutrients $\left(17 \mu \mathrm{mol} \mathrm{L}{ }^{-1} \mathrm{NO}_{3}{ }^{-}\right.$and $\left.1.0 \mu \mathrm{mol} \mathrm{L}{ }^{-1} \mathrm{PO}_{4}{ }^{3-}\right)$ were added to each incubation barrel

10 on day 1 . The response of dimethylated sulfur compounds was assessed during incubations of natural seawater assemblages under three triplicated $\mathrm{CO}_{2}$ treatments. The mean dimethylated sulfur compounds and Chl- $a$ concentrations and the bacterial abundance recorded in different treatments are shown in Table 2.

At the late stage of the experiment, significant differences in phytoplankton biomass were observed among the three treatments. Phytoplankton biomass and species were less in HC than in LC, and chrysophyceae (e.g., coccolith) and

15 cryptophyceae (e.g., Cryptomonas sp. and Rhodomonas sp.) disappeared during HC treatment. This result revealed that primary productivity was influenced by varied levels of acidity and the $\mathrm{pH}$ levels could influence the phytoplankton community structure. The results can be explained using the conclusion obtained by Deppeler et al. (2017) who supported the identification of a tipping point in the marine microbial community response to $\mathrm{CO}_{2}$ between $953 \mu \mathrm{atm}$ and $1140 \mu \mathrm{atm}$. When phytoplankton was exposed to a low $\mathrm{pH}$ level beyond their limits of tolerance, their growth rates and productivity

20 were declined obviously. During the experiment, diatom became increasingly dominant in the phytoplankton biomass. The average abundance of diatom was 4360 cells $\mathrm{L}^{-1}$ in $\mathrm{MC}$ treatment, which was higher than that in $\mathrm{LC}\left(2710\right.$ cells $\left.\mathrm{L}^{-1}\right)$ and $\mathrm{HC}$ (980 cells $\mathrm{L}^{-1}$ ) treatments on day 18 . However, the largest dinoflagellate abundance was observed in HC treatment with a value of 2210 cells $\mathrm{L}^{-1}$ on day 18. This shows that the effects of different acidity conditions on phytoplankton are different. Appropriate decrease in seawater $\mathrm{pH}$ may promote the growth of diatom and excessive reduction of acidity would retard its

25 growth. Compared with diatom, low $\mathrm{pH}$ conditions are more favorable for dinoflagellate growth.

Chl- $a$ is the main indicator of phytoplankton biomass, and its concentrations during the experiment were associated with phytoplankton biomass. The change in Chl- $a$ concentrations for each of the nine barrels and averages over the triplicate treatments is shown in Fig. 2. The Chl- $a$ concentrations of three parallel treatments which had the same pH level showed similar variation trends and the curves of Chl- $a$ concentration include logarithmic phase, stable and decline phases,

30 indicating that the communities of each paratactic treatment under different acidic conditions showed similar behaviors over the course of the experiment. Following nutrient addition, a strong phytoplankton bloom proceeded in all treatments. Phytoplankton abundances (Chl-a) peaked at nearly the same time (days 7-8) in all of the barrels. The maximum Chl- $a$ concentrations of $12.6 \mu \mathrm{g} \mathrm{L}^{-1}$ appeared in M3 (LC treatment) and the lowest concentrations of $4.27 \mu \mathrm{g} \mathrm{L}$ was observed in 
Biogeosciences Discuss., https://doi.org/10.5194/bg-2017-453

Manuscript under review for journal Biogeosciences

Discussion started: 2 November 2017

(c) Author(s) 2017. CC BY 4.0 License.

M9 (HC treatment) (Fig. 2a). Subsequent to the remarkable Chl- $a$ peak, the concentrations rapidly decreased, and the minimum value was observed at the end of the experiment. The mean values of Chl- $a$ concentrations for the whole experiment were $3.14 \pm 3.22,2.60 \pm 2.31$, and $2.14 \pm 1.72 \mu \mathrm{g} \mathrm{L}^{-1}$ for LC, MC, and HC treatments, respectively (Fig. 2b). As can be seen, a significant decrease in mean Chl- $a$ concentrations under MC and HC treatments was observed, with a mean $17 \%$

5 and $32 \%$ decrease, respectively. However, these large decrease showed no significant statistical differences between the treatments compared with the LC treatments during the entire experiment (for $\mathrm{MC}: \mathrm{T}=0.53, \mathrm{DF}=28, \mathrm{p}=0.600$; for $\mathrm{HC}$ : $\mathrm{T}$ $=1.055, \mathrm{DF}=28, \mathrm{p}=0.300)$. Nevertheless, obvious differences were observed in the Chl- $a$ concentrations between the LC and HC treatments during days 8-13 (T-test: $\mathrm{T}=2.393, \mathrm{DF}=8, \mathrm{p}=0.044$ ), indicating that change of seawater $\mathrm{pH}$ had a great influence on phytoplankton biomass in the intermediate stage of this acidification experiment.

\section{$10 \quad$ 3.1.3 Sulfur compounds}

DMS production followed the development and decline of the phytoplankton bloom (Figs. 2 and 3 ). Maximum DMS concentrations coincided with the highest Chl- $a$ concentrations in LC $\left(55.76 \mathrm{nmol} \mathrm{L}{ }^{-1}\right)$ and $\mathrm{MC}(44.86 \mathrm{nmol} \mathrm{L})$ treatments. However, the maximum DMS concentrations in the $\mathrm{HC}$ treatment $\left(30.58 \mathrm{nmol} \mathrm{L}{ }^{-1}\right)$ were delayed by 2 days relative to the highest Chl- $a$ concentrations. This may be because the acidification condition has a greater impact on the production and

15 release of DMS during the logarithmic growth phase of algae. The rate of increase was significantly higher in LC treatments than that in MC and HC treatments. The time integrated mean concentration of DMS at HC $\left(10.65 \mathrm{nmol} \mathrm{L}^{-1}\right)$ and MC $(13.42$ nmol L ${ }^{-1}$ ) levels was $35 \%$ and $19 \%$ lower than that at LC level (16.50 nmol L $\left.{ }^{-1}\right)$, respectively. DMS showed statistically significant differences between LC and HC treatments during days 6-11 ( $\mathrm{T}=2.492, \mathrm{DF}=8, \mathrm{p}=0.037$ ). Results were consistent with those of Wingenter et al. (2007).

20 For all $\mathrm{CO}_{2}$ treatments, DMSPd and particulate DMSP (DMSPp) concentrations ranged within 2.88-83.21 nmol $\mathrm{L}^{-1}$ (mean $19.37 \mathrm{nmol} \mathrm{L}^{-1}$ ) and 12.91-147.63 nmol L ${ }^{-1}$ (mean $60.65 \mathrm{nmol} \mathrm{L}^{-1}$ ) in the incubation barrels, respectively (Fig. 4 and Table 2). The DMSPd concentrations in M1, M3, M4, M8, and M9 increased continuously until day 8 and decreased afterward until the end of the experiment. M2, M5, M6, and M7 also exhibited a secondary increase during the final 4-5 days of the experiment. The maximum of M7 (HC treatment) was delayed by 3 days (Fig. 4a). The pH decrease from 7.9 to

257.7 caused an increase in the mean DMSPd from $23.7 \mathrm{nmol} \mathrm{L}{ }^{-1}$ in the MC treatment to $27.7 \mathrm{nmol} \mathrm{L}{ }^{-1}$ in the $\mathrm{HC}$ treatment (Fig. 4b) from day 6 to 16 of the experiment. However, in general, no difference was observed in DMSPd concentrations among treatments. DMSPp concentrations varied over the time course of the experiment. Although mean concentrations decreased by $17 \%$ and $21 \%$ under medium and high $\mathrm{CO}_{2}$ treatments, respectively, these differences were also not statistically significant. The effects on DMSP were rather insignificant than those on DMS, it seems that there was a great influence of 30 acidification on the conversion of DMSP to DMS.

Variations in DMSOd and DMSOp concentrations in all cultures are shown in Figs. 5a and 5c. The temporal trends of DMSOd in the nine treatments were significantly different. Under LC treatments, DMSOd concentrations peaked on days 8, 9, and 18 (Figs. 5a and 5b). By contrast, the DMSOd concentrations of MC and HC treatments, particularly M5, M6, M8, 
Biogeosciences Discuss., https://doi.org/10.5194/bg-2017-453

Manuscript under review for journal Biogeosciences

Discussion started: 2 November 2017

(c) Author(s) 2017. CC BY 4.0 License.

and M9, showed a slight increase, which presented no concurrence with the trend in Chl- $a$ or DMS (Figs. 2a, 3a, and 5a). In all treatments, an overall increase was observed in DMSOp concentrations with time. The DMSOp concentrations in most $\mathrm{CO}_{2}$ treatments rapidly increased during the initial part of the experiment with a maximum value at days 10-11 and remained stable afterward (Figs. 5c and 5d). DMSOd concentrations showed notable difference during days 3-10 and $\mathrm{CO}_{2}$ treatment exerted no significant effects on DMSOp concentrations during the experiment.

\subsubsection{Bacteria}

Bacteria can utilize DMSP as a growth substrate to produce DMS (Toole et al., 2008; Yoch et al., 1997) and they can convert DMS and DMSO into each other through oxidation or reduction processes, thereby playing an essential role in the biogeochemical cycle of sulfur. Piontek et al. (2010) showed that bacterial ectoenzyme activities are sensitive to changes in

$10 \mathrm{pH}$ levels; thus, the present work investigated the potential effect of bacteria on dimethylated sulfur compounds concentrations under different $\mathrm{pH}$ conditions. In this research, the mean bacterial abundance increased with increased $\mathrm{CO}_{2}$ levels and ranged from $0.29 \times 10^{8}$ cells $\mathrm{L}^{-1}$ to $9.60 \times 10^{8}$ cells $\mathrm{L}^{-1}$, with the maximum appearing in $\mathrm{HC}$ treatment. This result is consistent with that obtained by Deppeler et al. (2017) who suggested that bacterial abundance in treatment $\geq 634 \mu$ atm increased with increasing $\mathrm{CO}_{2}$. However, examination of individual coefficients revealed that these differences under $\mathrm{pH}$

15 treatments were not statistically significant. Previous literatures (Grossart et al., 2006; Allgaier et al., 2008; Liu et al., 2010; Avgoustidi et al., 2012) indicated that high $\mathrm{CO}_{2}$ levels had little or no effect on bacterial abundance. The difference of bacterial abundance among treatments would not be directly caused by $\mathrm{pH}$ change. Bacteria appeared to be relatively tolerant to ocean acidification, and bacterial abundance was indirectly affected by the responses of phytoplankton to ocean acidification (Grossart et al., 2006; Piontek et al., 2013; Deppeler et al., 2017). Thus, the high bacterial abundance in M7-M9

20 group may result from an increased dead phytoplankton at reduced $\mathrm{pH}$. Algal-derived organic matter was released during this decline process of phytoplankton and provided a labile energy and carbon source to bacteria in form of structural cell components and storage glucan (Smith et al., 1995).

\subsection{DMS and DMSP concentration response to the interaction among OA, solar radiation, and warming}

\subsubsection{Solar radiation}

25 In order to assess the community-level response to the ocean change in future $\mathrm{CO}_{2}$ and light conditions, photolysis rate constants $\left(K, \mathrm{~d}^{-1}\right)$ for DMS were calculated. The result showed that the natural logarithm of DMS concentrations had a good linear relationship with time, so the photodegradation of DMS follows a pseudo-first-order kinetics (Bouillon and Miller, 2005; Brugger et al., 1998). $K$ can be calculated by the slope of the regression line of natural logarithm of DMS concentrations against time. DMS loss was observed under full-spectrum natural light, UVB, UVA, visible light, and dark

30 conditions in each $\mathrm{pH}$ treatment. DMS photolysis rate constants were significantly different in various conditions (Table 3). Furthermore, no significant loss in DMS was observed in the dark during control experiments. The rate constants of DMS 
Biogeosciences Discuss., https://doi.org/10.5194/bg-2017-453

Manuscript under review for journal Biogeosciences

Discussion started: 2 November 2017

(c) Author(s) 2017. CC BY 4.0 License.

photolysis were in the range of 4.02-6.32, 1.13-4.73, 1.35-2.37, and 0.24-0.52 $\mathrm{d}^{-1}$ under full-spectrum natural light, UVB, UVA, and visible light with average values of 5.18, 3.02, 1.75, and $0.41 \mathrm{~d}^{-1}$, respectively (Table 3). The rate constants of DMS photolysis under full-spectrum natural light were higher than those under UVB, UVA, and visible light. The UVB made an important contribution to DMS photodegradation. The rate constants of DMS photolysis increased with decreasing

5 pH levels under full-spectrum natural light and UVB. However, a complete and contrasting result was obtained under UVA and visible light. The contributions to the total photolysis of UVB under decreasing $\mathrm{pH}$ conditions were increased from $28.0 \%$ to $74.9 \%$. On the contrary, the contributions of UVA and visible light were decreased from $59.1 \%$ to $21.3 \%$ and from $12.9 \%$ to $3.83 \%$, respectively (Table 3). These rate constants and the initial DMS concentration were used to calculate the DMS photolysis turnover time ( $\tau$ photo, $\mathrm{d}$ ). The turnover time for the upper $1 \mathrm{~m}$ of the water column under full-spectrum natural light ranged from $0.76 \mathrm{~d}$ to $1.19 \mathrm{~d}$ with an average value of $0.96 \mathrm{~d}$.

\subsubsection{Temperature}

DMS and DMSPp concentrations were recorded after $8 \mathrm{~h}$ under six cross-over incubation experiments with a full factorial combination of $\mathrm{LC}, \mathrm{MC}$, and $\mathrm{HC}$ treatments under ambient temperature and high-temperature treatments $\left(12{ }^{\circ} \mathrm{C}+\mathrm{pH} 8.1\right.$, $12{ }^{\circ} \mathrm{C}+\mathrm{pH} 7.9,12{ }^{\circ} \mathrm{C}+\mathrm{pH} \mathrm{7.7,} 18{ }^{\circ} \mathrm{C}+\mathrm{pH} \mathrm{8.1,18}{ }^{\circ} \mathrm{C}+\mathrm{pH} 7.9$, and $18{ }^{\circ} \mathrm{C}+\mathrm{pH} 7.7$; Fig. 6).

The mean DMS ranged from $3.90 \pm 0.11 \mathrm{nmol} \mathrm{L}^{-1}\left(12{ }^{\circ} \mathrm{C}+\mathrm{pH} 7.7\right)$ to $6.80 \pm 0.22 \mathrm{nmol} \mathrm{L^{-1 }}\left(18{ }^{\circ} \mathrm{C}+\mathrm{pH} 7.9\right)(\mathrm{Fig}$. 6a). Under ambient temperature condition $\left(12^{\circ} \mathrm{C}\right)$, the average DMS concentration at $\mathrm{pH} 7.7\left(3.90 \pm 0.11 \mathrm{nmol} \mathrm{L}{ }^{-1}\right) \mathrm{was}^{\mathrm{about}}$ $35 \%$ lower than that at $\mathrm{pH} 8.1\left(6.01 \pm 0.70 \mathrm{nmol} \mathrm{L}{ }^{-1}\right)$. No statistically significant difference was observed in the mean DMS concentrations between LC and MC ( $\mathrm{p}=0.328)$. However, statistically significant differences were observed between LC and $\mathrm{HC}(\mathrm{p}=0.005)$. For DMSPp, the average concentrations at $18{ }^{\circ} \mathrm{C}$ were higher than that at $12{ }^{\circ} \mathrm{C}$. For instance, the mean

20 DMSPp increased from $24.3 \pm 1.37 \mathrm{nmol} \mathrm{L}{ }^{-1}$ at $12{ }^{\circ} \mathrm{C}$ under $\mathrm{pH} 8.1$ treatment to $27.0 \pm 1.01 \mathrm{nmol} \mathrm{L}{ }^{-1}$ at $18{ }^{\circ} \mathrm{C}$ under $\mathrm{pH} 8.1$

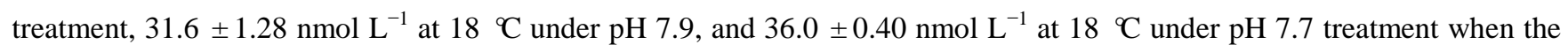
temperature increased from $12{ }^{\circ} \mathrm{C}$ to $18{ }^{\circ} \mathrm{C}$ (Fig. 6b). Temperature significantly affected (p < 0.001 ) the DMSPp concentrations, and the effects outweighed the effects of $\mathrm{pH}$ decrease. The concentrations of DMSPp showed significant differences among three treatments $(\mathrm{p} \leq 0.008)$ for high-temperature treatments and minimal differences under ambient temperature treatments. Results from two-way ANOVA illustrated the interaction between temperature and pH on DMSPp concentration $(\mathrm{p}=0.001)$. This indicated that the $\mathrm{pH}$ and temperature influenced the biological production of the dimethylated sulfur compounds in seawater. 
Biogeosciences Discuss., https://doi.org/10.5194/bg-2017-453

Manuscript under review for journal Biogeosciences

Discussion started: 2 November 2017

(c) Author(s) 2017. CC BY 4.0 License.

\section{Discussion}

\subsection{The effect of OA}

\subsubsection{The effect of OA on the variation of DMS, DMSP, DMSO, and Chl- $a$ concentrations}

The mean concentration of Chl- $a$ was significantly lower under HC treatments with decreases of $32 \%$. The low pH 5 conditions may influence the membrane electrochemical potential, enzyme activity (Kramer et al., 2003; Milligan et al., 2009), and $\mathrm{CO}_{2}$-concentrating mechanisms (CCMs) in phytoplankton (Rost et al., 2003; Wu et al., 2010), which affect primary productivity and growth rate (Gao et al., 2012a, 2012b). The phytoplankton biomass at this station, particularly that of coccolith, Cryptomonas sp. and Rhodomonas sp., was negatively affected at the lowest $\mathrm{pH}$ level.

Differences in Chl- $a$ could be responsible for differences in the production of dimethylated sulfur compounds. The DMS

10 concentrations measured in the experiment were significantly low under $\mathrm{HC}$ treatments (Fig. 3) with mean decreases of $35 \%$. This result was in agreement with the study of Avgoustidi (2006) that also showed substantially low DMS production under high $\mathrm{CO}_{2}$ levels. Nevertheless, changes in $\mathrm{pH}$, which was adjusted during the experiment, showed no or minimal effects on DMSPd/p concentrations. This phenomenon may be caused by the higher percentage of dinoflagellates, which are a prolific DMSP producer, in HC treatment than that in LC treatment, although the total amount of algae was lower in the former than

15 in the latter. Similarly, DMSOd/p concentrations presented distinct patterns with DMS and showed less difference among three treatments, particularly DMSOp. The effects on DMSP and DMSO were less pronounced than that for DMS, it seems that there was a great influence of acidification on the conversion of DMSP/DMSO to DMS. It could be inferred that changes in other biological and physical processes in response to changes in $\mathrm{pH}$ cannot be ruled out. The processes involved in DMS conversion included bacterial and phytoplankton production/uptake, viral lysis, and grazing (Wingenter et al., 2007).

20 Low $\mathrm{pH}$ affected one or more of these processes, thereby possibly causing the large decrease in DMS. Thus, differences in DMS may be seen as a result of changes in the whole ecosystems caused by different $\mathrm{pH}$ levels.

\subsubsection{Relationships among DMS, DMSP, DMSO, Chl-a, and bacteria}

A correlation coefficient matrix was calculated based on dimethylated sulfur compounds and Chl- $a$ concentrations in the three different $\mathrm{CO}_{2}$ treatments (Table 4) to evaluate quantitative similarities and differences of mean DMS, DMSP, DMSO, and Chl- $a$ concentrations in different $\mathrm{CO}_{2}$ treatments. Chl- $a$ and DMS, Chl- $a$ and DMSPd, DMS and DMSPd, and DMSPp and DMSOp all showed significant positive correlations in all treatments. Moreover, Chl- $a$ and DMSPp, DMS and DMSPp, DMS and DMSOd, and DMSPd and DMSOd showed a correlation in the LC treatments. However, no correlation was observed in the MC and HC treatments. On the contrary, DMSOp and DMSOd, and DMSPp and DMSOd showed significant positive correlations only in $\mathrm{HC}$ treatments. These relationships implied that OA may affect the biological

30 activity of algae and the production and consumption processes of sulfur compounds, which consequently affect their distribution and circulation. 
Biogeosciences Discuss., https://doi.org/10.5194/bg-2017-453

Manuscript under review for journal Biogeosciences

Discussion started: 2 November 2017

(c) Author(s) 2017. CC BY 4.0 License.

Given that algae are the sole producers of DMSP, direct correlations were observed between both DMS and DMSP levels and Chl- $a$. The correlations were relativity weakened with increased $\mathrm{CO}_{2}$ level. The correlation between DMSPp and Chl- $a$ also disappeared under relatively high $\mathrm{CO}_{2}$ levels. This phenomenon might be caused by the changed amount and proportion of various algae under high $\mathrm{CO}_{2}$ conditions. Furthermore, DMS concentrations showed a strong correlation with DMSPd

5 under LC treatment. By contrast, a weak correlation was observed with DMSPp under LC treatment, and no correlation was observed under MC and HC treatments. An overlap between the peaks of DMS and DMSPd and peaks of Chl- $a$ is shown in Figs. 2, 3, and 4. DMS and DMSPd also showed their highest peaks with relatively low DMSPp concentrations. This phenomenon might indicate that grazing by zooplankton or senescence of algal cells presents a stronger effect on DMS and DMSP concentrations in MC and HC treatments than in LC treatment. Grazing zooplankton on DMSP-producing algae can

10 increase DMSPd and DMS concentrations (Archer et al., 2002; Simó et al., 2002; Wolfe and Steinke, 1996). Nguyen et al. (1988) showed that DMSP-producing algae are largely responsible for the production of DMSPd and DMS in seawater during their senescence.

A significant correlation between DMS and DMSOd was observed in LC treatments (Table 4). The result was in accordance with the findings of Hatton et al. (2004) and Zindler-Schlundt et al. (2015) who showed that DMSO and DMS

15 are closely related because of the direct formation of DMSO via bacterial DMS oxidation. The close link between DMS and DMSOd was not observed in MC and HC treatments. The changes in the production, consumption, and degradation processes which caused by the decreasing $\mathrm{pH}$ might mask the relationship between DMS and DMSOd. In addition, DMSPd concentration showed an obvious correlation with DMSOd only in LC treatments for the entire duration of the experiment (Table 4). DMSPd may be cleaved to DMS by specific bacteria that contain DMSP lyase (Curson et al., 2008), followed by

20 the bacterial oxidation of DMS to DMSOd. This relationship was not found in MC and HC treatments. The phenomenon might be caused by the change in phytoplankton community and bacterial oxidation of DMS to DMSO.

The bacterial consumption of DMS is an important process, and one which if rapid enough, cannot result in increase in seawater DMS concentrations (Kiene and Bates, 1990). The mean bacterial abundance under HC treatments was a maximum

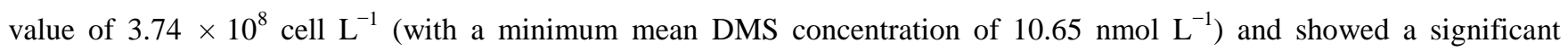

25 relationship with DMS concentration (Fig. 7). This result indicated that lowered DMS concentrations under HC treatment were in part a result of the enhanced bacterial uptake of DMS in high $\mathrm{CO}_{2}$ conditions. Crawfurd et al. (2016) and Spilling et al. (2016) reported that bacterial grazing and viral lysis were higher in the high $\mathrm{CO}_{2}$ treatments during periods of the experiment, and these processes can accelerate the release of dimethylated sulfur compounds from phytoplankton cells to some extent (Dacey and Wakeham, 1986). This agrees well with our inference mentioned in section 4.1.1. In addition,

30 bacterial abundance was correlated with DMS and DMSOd concentrations in the three kinds of treatments. This result suggested that bacterial degradation of DMSP was an important source of DMS, and bacterial production of DMSOd might be an important source of DMSOd in the incubation experiment. 
Biogeosciences Discuss., https://doi.org/10.5194/bg-2017-453

Manuscript under review for journal Biogeosciences

Discussion started: 2 November 2017

(c) Author(s) 2017. CC BY 4.0 License.

\subsubsection{DMS/Chl- $a$, DMSPt/Chl- $a$, and DMSOt/Chl- $a$ ratios}

The ratios of DMS/Chl- $a$, DMSPt/Chl- $a$, and DMSOt/Chl- $a$ are presented in Fig. 8. The ratios provide a good indication of the relative strength of DMS, DMSP, and DMSO production by the phytoplankton assemblage at different stages of the experiment. Moreover, these ratios can highlight where the ecosystem shifts may have occurred. The ratios showed a drastic

5 decline during the first weekend and subsequently a slow increase in the later period. The ratios of DMS to Chl- $a$ showed minimal differences at the three $\mathrm{CO}_{2}$ levels with an average of $8 \%$ less DMS produced per Chl- $a$ under MC treatment. However, this trend was reversed for the ratios of DMSPt and DMSOt to Chl-a separately with $22 \%$ and $15 \%$ more production per Chl- $a$ in the HC treatment compared with the LC treatment. Under MC treatments, the highest ratio values of DMS/Chl- $a$, DMSPt/Chl- $a$ and DMSOt/Chl- $a$ were observed on the last day. These ratios showed similar trends during the 10 experiment, and no pronounced difference was found in these ratios at the three $\mathrm{CO}_{2}$ levels. The results indicated no difference in the dimethylated sulfur compounds production in terms of phytoplankton biomass.

\subsection{The effect of the interaction between $\mathrm{OA}$ and environmental factors}

The photolysis rate constants of DMS were strongly affected by solar radiation and OA. The net effects of OA on DMS production were largely dependent on light conditions. Relatively, significant change was observed in $\mathrm{K}_{\mathrm{UVB}}$ and $\mathrm{K}_{\mathrm{UVA}}$,

15 particularly $\mathrm{K}_{\mathrm{UVB}}$ increased by four times at $\mathrm{pH} 7.7$ compared at $\mathrm{pH} 8.1$, indicating that reduced $\mathrm{pH}$ levels accelerated the photodegradation of DMS under UVB conditions. The result was mainly because photodegradation of DMS was related to inducement of some oxidants (such as singlet oxygen, hydroxyl radical, hydrogen peroxide, and photoactivated CDOM) (Kieber et al., 1996; Brimblecombe and Shooter, 1986) and some ions (such as $\mathrm{HCO}_{3}{ }^{-}, \mathrm{CO}_{3}{ }^{2-}$, $\mathrm{NO}_{3}{ }^{-}$, and $\mathrm{Br}^{-}$) $(\mathrm{Bouillon}$ and Miller, 2005). The short wavelength UVB played a decisive role in the formation and reaction of these oxidants and pH 20 simultaneously influenced the free-radical production/scavenging processes involving ions, which may be responsible for the variation in photodegradation rate under different sunlight and $\mathrm{pH}$ conditions. Although the interaction of acidification and solar radiation is considerably complex, an overall decrease of $\mathrm{pH}$ in UVB would result in an eventual decrease in DMS, indicating that ocean acidification can promote DMS photooxidation under UVB. OA is not proceeding in isolation (Gao et al., 2012). The effect of the interaction between OA and environmental conditions complicates the overall ecosystem

25 response. Hence, comprehensive consideration of OA and solar radiation can better interpret and understand feedbacks between $\mathrm{OA}$ and global climatic change.

Figure 6 shows the DMS and DMSPp concentration variabilities under increased $\mathrm{CO}_{2}$ and temperature. These data illustrated that temperature and $\mathrm{pH}$ exhibited a significant interactive effect on DMS and DMSPp productions $(\mathrm{p}=0.001)$. The highest DMS and DMSPp concentrations were observed at $18{ }^{\circ} \mathrm{C}$ under $\mathrm{pH} 7.9$ and $\mathrm{pH} 7.7$, respectively. This result

30 indicated that temperature may regulate the effect of $\mathrm{pH}$ on DMS and DMSPp productions. Therefore, global environmental change manifesting in $\mathrm{OA}$ and warming may not result in a decreased DMS as suggested by the effect of elevated $\mathrm{CO}_{2}$ in isolation. 
Biogeosciences Discuss., https://doi.org/10.5194/bg-2017-453

Manuscript under review for journal Biogeosciences

Discussion started: 2 November 2017

(c) Author(s) 2017. CC BY 4.0 License.

Experimental results can only be hypothesized because information on specific classification of DMS-utilizing bacteria in the experiment is not available. Although such variability in DMS, DMSP, and DMSO concentrations existed during the short-term incubation experiment, whether the differences can be attributed to the effect of $\mathrm{pH}$ still remains unclear. Considering the complex interactive effects of environmental factors, an accurate model with appropriate parameterization of

5 the environmental factors should be developed, and such model can improve our understanding of the earth system's response to predicted global environmental change.

\section{Conclusion}

This study shows the influence of OA on the phytoplankton community structure and concentrations of Chl- $a$, DMS, DMSP, and DMSO in a deck incubation experiment. Concentrations were monitored over the growth and decline of the bloom.

10 Compared with ambient $\mathrm{CO}_{2}$ levels, the average concentrations of Chl- $a$, DMS, DMSPp, and DMSOd were reduced by approximately 17\%, 19\%, 17\%, and 16\% under MC treatment and by 32\%, 35\%, 21\%, and 16\% under HC treatment, respectively. By contrast, DMSPd and DMSOp concentrations showed minimal changes under three conditions. Instead of reduction, the ratios of DMSPt/Chl- $a$ and DMSOt/Chl- $a$ were respectively $22 \%$ and $15 \%$ higher under HC treatment than under LC treatment. Furthermore, the oxidation-reduction effects of bacteria also played an important role in concentrations

15 of dimethylated sulfur compounds. In this study, the reason for the difference of dimethylated sulfur compounds concentrations among three treatments could be mainly due to the combined results of changes in phytoplankton production and bacterial metabolism and activity. Additional experiment about the interaction between OA and environmental factors showed that warming can potentially mitigate the drastic effects of increased $\mathrm{CO}_{2}$ levels on DMS and DMSPp productions. In addition, the photodegradation process of DMS was strongly influenced by solar radiation under high $\mathrm{CO}_{2}$ levels.

20 The response described above illustrated the effect of a relatively rapid increase of pH to the current phytoplankton community. OA might influence the DMS, DMSP, and DMSO concentrations in oceans. Further research is required to facilitate further understanding of the role of specific phytoplankton and bacteria taxa for dimethylated sulfur compounds production under OA and explain the effect of OA on DMS compound cycling in future acidic ocean.

25 Competing interests. The authors declare that they have no conflict of interest.

Acknowledgements. The authors thank the captain and the crew of the R/V "Run Jiang No. I" for help and cooperation during the two cruises. This work was financially supported by the National Natural Science Foundation of China (Grant Nos. 41320104008 and 41576073), the National Key Research and Development Program of China (Grant No.

30 2016YFA0601301), the National Natural Science Foundation for Creative Research Groups (Grant No. 41521064), AoShan Talents Program of Qingdao National Laboratory for Marine Science and Technology (No. 2015 ASTP). 
Biogeosciences Discuss., https://doi.org/10.5194/bg-2017-453

Manuscript under review for journal Biogeosciences

Discussion started: 2 November 2017

(c) Author(s) 2017. CC BY 4.0 License.

\section{References}

Allgaier, M., Riebesell, U., Vogt, M., Thyrhaug, R., and Grossart, H. P.: Coupling of heterotrophic bacteria to phytoplankton bloom development at different $\mathrm{pCO}_{2}$ levels: a mesocosm study, Biogeosciences, 5, 1007-1022, https://doi.org/10.5194/bg-5-1007-2008, 2008.

5 Archer, S. D., Smith, G. C., Nightingale, P. D., Widdicombe, C. E., Tarran, G. A., Rees, A. P., and BurkillP, H.: Dynamics of particulate dimethylsulphoniopropionate during a Lagrangian experiment in the northern North Sea, Deep Sea Res. Part II Top. Stud. Oceanogr., 49, 2979-2999, https://doi.org/10.1016/S0967-0645(02)00067-X, 2002.

Arnold, H. E., Kerrison, P., and Steinke, M.: Interacting effects of ocean acidification and warming on growth and DMSproduction in the haptophyte coccolithophore Emiliania huxleyi, Global Change Biol., 19, 1007-1016, https://doi.org/10.1111/gcb.12105, 2013.

Asher, E. C., Dacey, J. W. H., Stukel, M., Long, M. C., and Tortell, P. D.: Processes driving seasonal variability in DMS, DMSP, and DMSO concentrations and turnover in coastal Antarctic waters, Limnol. Oceanogr., 62, 104-124, https://doi.org/10.1002//no.10379, 2016.

Avgoustidi, V., Nightingale, P. D., Joint, I., Steinke, M., Turner, S. M., Hopkins, F. E., and Liss, P. S.: Decreased marine

dimethyl sulfide production under elevated $\mathrm{CO}_{2}$ levels in mesocosm and in vitro studies, Environ. Chem., 9, 399-404, https://doi.org/10.1071/EN11125, 2012.

Barnes, I., Hjorth, J., and Mihalopoulos, N.: Dimethyl sulfide and dimethyl sulfoxide and their oxidation in the atmosphere, Chem. Rev., 106, 940-975, https://doi.org/10.1021/cr020529+, 2006.

Bouillon, R. C., and Miller, W. L.: Photodegradation of dimethyl sulfide (DMS) in natural waters: Laboratory assessment of the nitrate-photolysis-induced DMS oxidation, Environ. Sci. Technol., 39, 9471-9477, https://doi.org/10.1021/es048022z, 2005.

Brimblecombe, P., and Shooter, D.: Photo-oxidation of dimethylsulphide in aqueous solution, Mar. Chem., 19, 343-353, https://doi.org/10.1016/0304-4203(86)90055-1, 1986.

Brugger, A., Slezak, D., Obernosterer, I., and Herndl, G. J.: Photolysis of dimethylsulfide in the northern Adriatic Sea: Dependence on substrate concentration, irradiance and DOC concentration, Mar. Chem., 59, 321-331, https://doi.org/10.1016/S0304-4203(97)00090-X, 1998.

Caldeira, K., and Wickett, M. E.: Oceanography: anthropogenic carbon and ocean pH, Nature, 425, 365-365, https://doi.org/10.1038/425365a, 2003.

Capotondi, A., Alexander, M. A., Bond, N. A., Curchitser, E. N., and Scott, J. D.: Enhanced upper ocean stratification with climate change in the CMIP3 models, J. Geophys. Res. Oceans, 117, 77-93, https://doi.org/10.1029/2011JC007409, 2012.

Charlson, R. J., Lovelock, J. E., Andreae, M. O., and Warren, S. G.: Oceanic phytoplankton, atmospheric sulphur, cloud albedo and climate, Nature, 326, 655-661, 1987. 
Biogeosciences Discuss., https://doi.org/10.5194/bg-2017-453

Manuscript under review for journal Biogeosciences

Discussion started: 2 November 2017

(c) Author(s) 2017. CC BY 4.0 License.

Crawfurd, K. J., Brussaard, C. P. D., and Riebesell, U.: Shifts in the microbial community in the Baltic Sea with increasing $\mathrm{CO}_{2}$, Biogeosciences, 169, 1-51, https://doi.org/10.5194/bg-2015-606, 2016.

Curson, A. R. J., Rogers, R., Todd, J. D., Brearley, C. A., and Johnston, A. W. B.: Molecular genetic analysis of a dimethylsulfoniopropionate lyase that liberates the climate-changing gas dimethylsulfide in several marine $\alpha$ proteobacteria and Rhodobacter sphaeroides, Environ. Microbiol., 10, 757-767, https://doi.org/10.1111/j.14622920.2007.01499.x, 2008.

Dacey, J. W., and Wakeham, S. G.: Oceanic dimethylsulfide: production during zooplankton grazing on phytoplankton, Science, 233, 1314-1316, https://doi.org/10.1126/science.233.4770.1314, 1986.

Deppeler, S., Petrou, K., Schulz, K. G., Westwood, K., Pearce, I., McKinlay, J., and Davidson, A.: Ocean acidification of a coastal Antarctic marine microbial community reveals a critical threshold for $\mathrm{CO}_{2}$ tolerance in phytoplankton productivity, Biogeosciences, 1-36, https://doi.org/10.5194/bg-2017-226, 2017.

Deschaseaux, E. S. M., Kiene, R. P., Jones, G. B., Deseo, M. A., Swan, H. B., Oswald, L., and Eyre, B. D.: Dimethylsulphoxide (DMSO) in biological samples: A comparison of the $\mathrm{TiCl}_{3}$ and $\mathrm{NaBH}_{4}$ reduction methods using headspace analysis, Mar. Chem., 164, 9-15, https://doi.org/10.1016/j.marchem.2014.05.004, 2014.

Dickson, A. G., and Millero, F. J.: A comparison of the equilibrium constants for the dissociation of carbonic acid in seawater media, Deep Sea Res. Part A Oceanogr. Res. Papers, 34, 1733-1743, https://doi.org/10.1016/01980149(87)90021-5, 1987.

Doney, S. C.: Oceanography: Plankton in a warmer world, Nature, 444, 695-696, https://doi.org/10.1038/444695a, 2006.

Fu, F. X., Warner, M. E., Zhang, Y., Feng, Y., and Hutchins, D. A.: Effects of increased temperature and $\mathrm{CO}_{2}$ on photosynthesis, growth, and elemental ratios in marine Synechococcus and Prochlorococcus (Cyanobacteria), J. Phycol., 43, 485-496, https://doi.org/10.1111/j.1529-8817.2007.00355.x, 2007.

Gabric, A. J., Cropp, R., Hirst, T., and Marchant, H.: The sensitivity of dimethyl sulfide production to simulated climate change in the Eastern Antarctic Southern Ocean, Tellus, 55, 966-981, https://doi.org/10.1034/j.1600-0889.2003.00077.x, 2010 .

25 Gao, K., Helbling, E. W., Häder, D. P., and Hutchins, D. A.: Responses of marine primary producers to interactions between ocean acidification, solar radiation, and warming, Mar. Ecol. Prog. Ser., 470, 167-189, https://doi.org/10.3354/meps10043, 2012 a.

Gao, K., Xu, J., Gao, G., Li, Y., Hutchins, D. A., Huang, B., Wang, L., Zheng, Y., Jin, P., Cai, X., Häder, D. P., Li, W., Xu, K., Liu, N., and Riebesell, U.: Rising $\mathrm{CO}_{2}$ and increased light exposure synergistically reduce marine primary productivity, Nature Clim. Change, 2, 519-523, https://doi.org/10.1038/nclimate1507, 2012b.

Grossart, H. P., Allgaier, M., Passow, U., and Riebesell, U.: Testing the effect of $\mathrm{CO}_{2}$ concentration on the dynamics of marine heterotrophic bacterioplankton, Limnol. Oceanogr., 51, 1-11, https://doi.org/10.4319/lo.2006.51.1.0001, 2006.

Hatton, A. D., Darroch, L. and Malin, G.: The role of dimethylsulphoxide in the marine biogeochemical cycle of dimethylsulphide, Oceanogr. Mar. Biol. Annu. Rev., 42, 29-55, https://doi.org/10.1201/9780203507810.ch2, 2004. 
Biogeosciences Discuss., https://doi.org/10.5194/bg-2017-453

Manuscript under review for journal Biogeosciences

Discussion started: 2 November 2017

(c) Author(s) 2017. CC BY 4.0 License.

Hatton, A. D., Shenoy, D. M., Hart, M. C., Mogg, A., and Green, D. H.: Metabolism of DMSP, DMS and DMSO by the cultivable bacterial community associated with the DMSP-producing dinoflagellate Scrippsiella trochoidea, Biogeochemistry, 110, 131-146, https://doi.org/10.1007/s10533-012-9702-7, 2012.

Hatton, A. D.: Influence of photochemistry on the marine biogeochemical cycle of dimethylsulphide in the northern North Sea, Deep Sea Res. Part II Top. Stud. Oceanogr., 49, 3039-3052, https://doi.org/10.1016/S0967-0645(02)00070-X, 2002.

Hays, G. C., Richardson, A. J., and Robinson, C.: Climate change and marine plankton, Trends Ecol. Evol., 20, 337-344, https://doi.org/10.1016/j.tree.2005.03.004, 2005.

Keller, M. D., Bellows, W. K., and Guillard, R. R.: Dimethyl sulfide production in marine phytoplankton, Biogenic Sulfur Environ., 393, 167-182, https://doi.org/10.1021/bk-1989-0393.ch011, 1989.

10 Kerrison, P., Suggett, D. J., Hepburn, L. J., and Steinke, M.: Effect of elevated pCO on the production of dimethylsulphoniopropionate (DMSP) and dimethylsulphide (DMS) in two species of Ulva (Chlorophyceae), Biogeochemistry, 110, 5-16, https://doi.org/10.1007/s10533-012-9707-2, 2012.

Kieber, D. J., Jiao, J., Kiene, R. P., and Bates, T. S.: Impact of dimethylsulfide photochemistry on methyl sulfur cycling in the equatorial Pacific Ocean, J. Geophys. Res. Oceans, 101, 3715-3722, https://doi.org/10.1029/95JC03624, 1996.

15 Kiene, R. P., and Bates, T. S.: Biological removal of dimethyl sulphide from sea water, Nature, 345, 702-705, https://doi.org/10.1038/345702a0, 1990.

Kiene, R. P., and Gerard, G.: Determination of trace levels of dimethylsulfoxide (DMSO) in seawater and rainwater, Mar. Chem., 47, 1-12, https://doi.org/10.1016/0304-4203(94)90009-4, 1994.

Kim, J. M., Lee, K., Yang, E. J., Shin, K., Noh, J. H., Park, K. T., Hyun, B., Jeong, H. J., Kim, J. H., Kim, K. Y., Kim, M., Kim, H. C., Jang, P. G., and Jang, M. C.: Enhanced production of oceanic dimethylsulfide resulting from $\mathrm{CO}_{2}$-induced grazing activity in a high $\mathrm{CO}_{2}$ world, Environ. Sci. Technol., 44, 8140-8143, https://doi.org/10.1021/es102028k, 2010.

Kramer, D. M., Cruz, J. A., and Kanazawa, A.: Balancing the central roles of the thylakoid proton gradient, Trends Plant Sci., 8, 27-32, https://doi.org/10.1016/S1360-1385(02)00010-9, 2003.

Liu, J., Weinbauer, M. G., Maier, C., Dai, M., Gattuso, J. P.: Effect of ocean acidification on microbial diversity and on microbe-driven biogeochemistry and ecosystem functioning, Aquat. Microb. Ecol., 61, 291-305, https://doi.org/10.3354/ame01446, 2010.

Malin, G., Wilson, W. H., Bratbak, G., Liss, P. S., and Mann, N. H.: Elevated production of dimethylsulfide resulting from viral infection of cultures of Phaeocystis pouchetii, Limnol. Oceanogr., 43, 1389-1393, https://doi.org/10.4319/1o.1998.43.6.1389, 1998.

30 Mélancon, J., Levasseur, M., Lizotte, M., Scarratt, M., Tremblay, J. E., Tortell, P., Yang, G. P., Shi, G. Y., Gao, H. W., Semeniuk, D., Robert, M., Arychuk, M., Johnson, K., Sutherland, N., Davelaar, M., Nemcek, N., Peña, A., and Richardson, W.: Impact of ocean acidification on phytoplankton assemblage, growth, and DMS production following Fedust additions in the NE Pacific high-nutrient, low-chlorophyll waters, Biogeosciences, 13, 1677-1692, https://doi.org/10.5194/bg-13-1677-2016, 2016. 
Biogeosciences Discuss., https://doi.org/10.5194/bg-2017-453

Manuscript under review for journal Biogeosciences

Discussion started: 2 November 2017

(c) Author(s) 2017. CC BY 4.0 License.

Milligan, A. J., Mioni, C. E., and Morel, F. M.: Response of cell surface $\mathrm{pH}$ to $\mathrm{pCO}_{2}$ and iron limitation in the marine diatom Thalassiosira weissflogii, Mar. Chem. 114, 31-36, https://doi.org/10.1016/j.marchem.2009.03.003, 2009.

Nakicenovic, N., and Swart, R.: Special report on emissions scenarios, Cambridge University Press, Cambridge, 612, 2000.

Nguyen, B. C., Belviso, S., Mihalopoulos, N., Gostan, J., and Nival, P.: Dimethyl sulfide production during natural phytoplanktonic blooms, Mar. Chem., 24, 133-141, https://doi.org/10.1016/0304-4203(88)90044-8, 1988.

Orr, J. C., Fabry, V. J., Aumont, O., Bopp, L., Doney, S. C., Feely, R. A., Gnanadesikan, A., Gruber, N., Ishida, A., Joos, F., Key, R. M., Lindsay, K., Maier-Reimer, E., Matear, R., Monfray, P., Mouchet, A., Najjar, R. G., Plattner, G. K., Rodgers, K. B., Sabine, C. L., Sarmiento, J. L., Schlitzer, R., Slater, R. D., Totterdell, I. J., Weirig, M. F., Yamanaka, Y., and Yool, A.: Anthropogenic ocean acidification over the twenty-first century and its impact on calcifying organisms, Nature, 437, 681-686, https://doi.org/10.1038/nature04095, 2005.

Park, K. T., Lee, K., Shin, K., Yang, E. J., Hyun, B., Kim, J. M., Noh, J. H., Kim, M., Kong, B., Choi, D. H., Choi, S. J., Jang, P. G., and Jeong, H. J.: Direct linkage between dimethyl sulfide production and microzooplankton grazing, resulting from prey composition change under high partial pressure of carbon dioxide conditions, Environ. Sci. Technol., 48: 47504756. https://doi.org/10.1021/es403351h, 2014.

15 Parsons, T. R., Maita, Y., and Lalli, C. M.: A manual of biological and chemical methods for seawater analysis, Oxford: Pergamon Press, 395, 475-490, 1984.

Piontek, J., Borchard, C., Sperling, M., and Schulz, K. G., Riebesell, U., and Engel, A.: Response of bacterioplankton activity in an Arctic fjord system to elevated $\mathrm{pCO}_{2}$ : results from a mesocosm perturbation study, Biogeosciences, 9, 297314, https://doi.org/10.5194/bg-10-297-2013, 2013.

20 Piontek, J., Lunau, M., Handel, N., Borchard, C., Wurst, M., and Engel, A.: Acidification increases microbial polysaccharide degradation in the ocean, Biogeosciences, 7, 1615-1624, https://doi.org/10.5194/bg-7-1615-2010, 2010.

Porter, K. G., and Feig, Y. S.: The use of DAPI for identifying and counting aquatic microflora, Limnol. Oceanogr., 25, 943948, https://doi.org/10.4319/lo.1980.25.5.0943, 1980.

Quinn, P. K., and Bates, T. S.: The case against climate regulation via oceanic phytoplankton sulphur emissions, Nature, 480, 51-56, https://doi.org/10.1038/nature10580, 2011.

Rap, A., Scott, C. E., Spracklen, D. V., Bellouin, N., Forster, P. M., Carslaw, K. S., and Mann, G.: Natural aerosol direct and indirect radiative effects, Geophys. Res. Lett., 40, 3297-3301, https://doi.org/10.1002/grl.50441, 2013.

Rost, B., Riebesell, U., Burkhardt, S., and Sültemeyer, D.: Carbon acquisition of bloom-forming marine phytoplankton, Limnol. Oceanogr., 48, 55-67, https://doi.org/10.4319/lo.2003.48.1.0055, 2003.

30 Shaw, G. E.: Bio-controlled thermostasis involving the sulfur cycle, Clim. Change, 5, 297-303, https://doi.org/10.1007/BF02423524, 1983.

Simó, R., Archer, S. D., Gilpin, L., and Stelfox-Widdicombe, C. E.: Coupled dynamics of dimethylsulfoniopropionate and dimethylsulfide cycling and the microbial food web in surface waters of the North Atlantic, Limnol. Oceanogr., 47, 53-61, https://doi.org/10.4319/1o.2002.47.1.0053, 2002. 
Biogeosciences Discuss., https://doi.org/10.5194/bg-2017-453

Manuscript under review for journal Biogeosciences

Discussion started: 2 November 2017

(c) Author(s) 2017. CC BY 4.0 License.

Smith, D. C., Steward, G. F., Long, R. A., Azam, F.: Bacterial mediation of carbon fluxes during A diatom bloom in A mesocosm, Deep Sea Res. Part II Top. Stud. Oceanogr., 42, 75-97, https://doi.org/10.1016/0967-0645(95)00005-B, 1995.

Spiese, C. E., Kieber, D. J., Nomura, C. T., and Kiene, R. P.: Reduction of dimethylsulfoxide to dimethylsulfide by marine phytoplankton, Limnol. Oceanogr., 54, 560-570, https://doi.org/10.4319/lo.2009.54.2.0560, 2009.

5 Spilling, K., Kai, G. S., Paul, A. J., Boxhammer, T., Achterberg, E. P., Hornick, T., Lischka, S., Stuhr, A., Bermúdez, R., Czerny, J., Crawfurd, K., Brussaard, C. P. D., Grossart, H. P., and Riebesell, U.: Effects of ocean acidification on pelagic carbon fluxes in a mesocosm experiment, Biogeosciences, 13, 1-30, https://doi.org/10.5194/bg-2016-56, 2016.

Stefels, J., Steinke, M., Turner, S., Malin, G., and Belviso, S.: Environmental constraints on the production and removal of the climatically active gas dimethylsulphide (DMS) and implications for ecosystem modelling, Biogeochemistry, 83, 245275, https://doi.org/10.1007/s10533-007-9091-5, 2007.

Toole, D. A., and Siegel, D. A.: Light-driven cycling of dimethylsulfide (DMS) in the Sargasso Sea: Closing the loop, Geophys. Res. Lett., 31, 111-142, https://doi.org/10.1029/2004GL019581, 2004.

Toole, D. A., Siegel, D. A. and Doney, S. C.: A light-driven, onedimensional dimethylsulfide biogeochemical cycling model for the Sargasso Sea, J. Geophys. Res. Biogeosci., 113, 385-393, https://doi.org/10.1029/2007JG000426, 2008.

15 Vogt, M., Steinke, M., Turner, S., Paulino, A., Meyerhöfer, M., Riebesell, U., and Liss, P.: Dynamics of dimethylsulphoniopropionate and dimethylsulphide under different $\mathrm{CO}_{2}$ concentrations during a mesocosm experiment, Biogeosciences, 5, 407-419, https://doi.org/10.5194/bg-5-407-2008, 2008.

Wakeham, S. G.: Oceanic dimethylsulfide: production during zooplankton grazing on phytoplankton, Science, 233, 13141316, https://doi.org/10.1126/science.233.4770.1314, 1986.

20 Wingenter, O. W., Haase, K. B., Zeigler, M., Blake, D. R., Rowland, F. S., Sive, B. C., Paulino, A., Thyrhaug, R., Larsen, A., Schulz, K., Meyerhöfer, M., and Riebesell, U.: Unexpected consequences of increasing $\mathrm{CO}_{2}$ and ocean acidity on marine production of DMS and $\mathrm{CH}_{2} \mathrm{CII}$ : Potential climate impacts, Geophys. Res. Lett., 34, 223-224, https://doi.org/10.1029/2006GL028139, 2007.

Wolfe, G. V., and Steinke, M.: Grazing-activated production of dimethyl sulfide (DMS) by two clones of Emiliania huxleyi, Limnol. Oceanogr., 41, 1151-1160, https://doi.org/10.4319/lo.1996.41.6.1151, 1996.

Wolfe, G. V., Levasseur, M., Cantin, G., and Michaud, S.: DMSP and DMS dynamics and microzooplankton grazing in the Labrador Sea: application of the dilution technique, Deep Sea Res., Part I, 47, 2243-2264, https://doi.org/10.1016/S09670637(00)00028-5, 2000.

$\mathrm{Wu}, \mathrm{Y} ., \mathrm{Gao}, \mathrm{K}$. and Riebesell, U.: $\mathrm{CO}_{2}$-induced seawater acidification affects physiological performance of the marine diatom Phaeodactylum tricornutum, Biogeosciences, 7, 2915-2923, https://doi.org/10.5194/bg-7-2915-2010, 2010.

Yoch, D. C., Ansede, J. H., and Rabinowitz, K. S.: Evidence for intracellular and extracellular dimethylsulfoniopropionate (DMSP) lyases and DMSP uptake sites in two species of marine bacteria, Appl. Environ. Microb., 63, 3182-3188, 1997. 
Biogeosciences Discuss., https://doi.org/10.5194/bg-2017-453

Manuscript under review for journal Biogeosciences

Discussion started: 2 November 2017

(c) Author(s) 2017. CC BY 4.0 License.

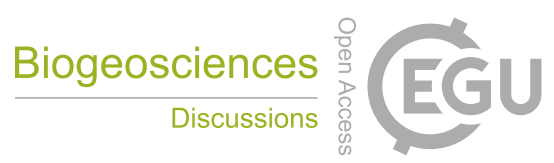

(c) (i)

Zhang, H. H., Yang, G. P., and Zhu, T.: Distribution and cycling of dimethylsulfide (DMS) and dimethylsulfoniopropionate (DMSP) in the sea-surface microlayer of the Yellow Sea, China, in spring, Cont. Shelf Res., 28, 2417-2427, https://doi.org/10.1016/j.csr.2008.06.003, 2008.

Zindler-Schlundt, C., Lutterbeck, H., Endres, S., and Bange, H. W.: Environmental control of dimethylsulfoxide (DMSO) cycling under ocean acidification, Environ. Chem., 13, 330-339, https://doi.org/10.1071/EN14270, 2015. 
Biogeosciences Discuss., https://doi.org/10.5194/bg-2017-453

Manuscript under review for journal Biogeosciences

Discussion started: 2 November 2017

(c) Author(s) 2017. CC BY 4.0 License.

(c) (i)

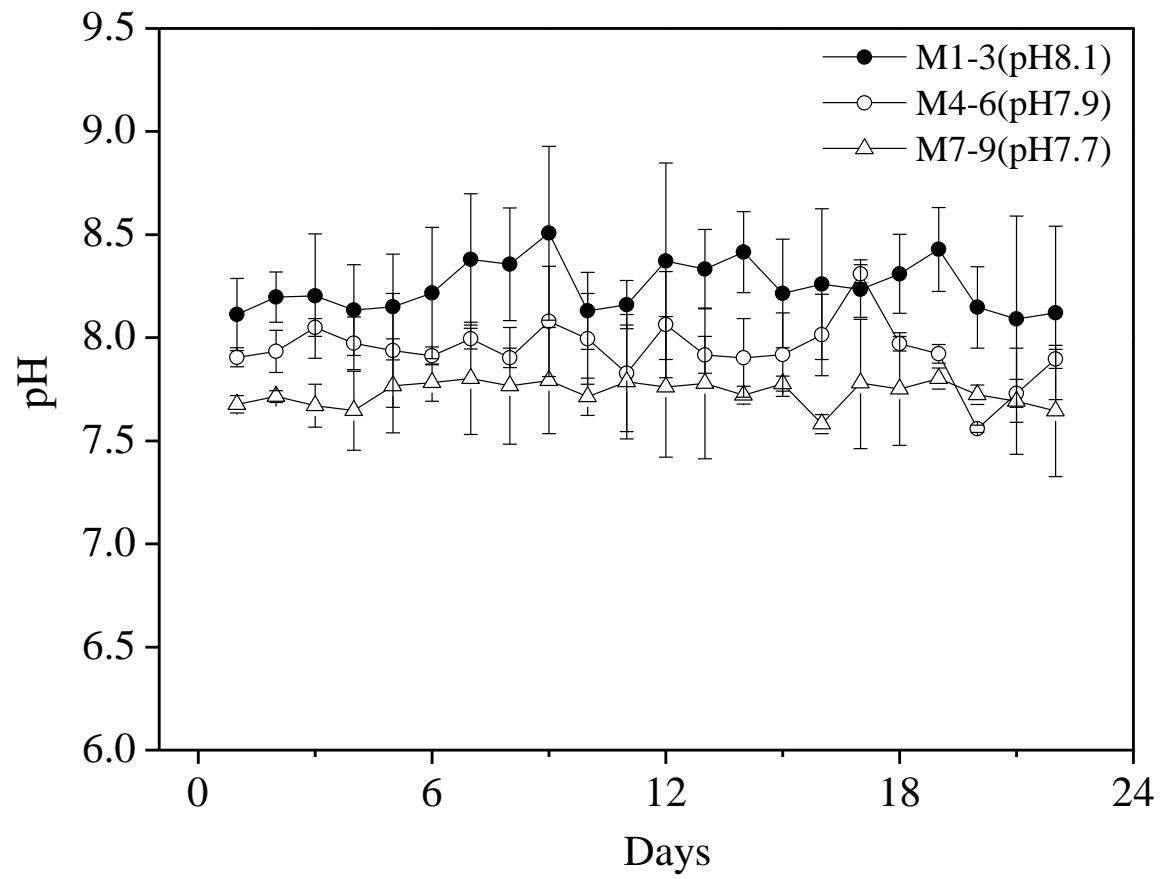

Figure 1. Temporal changes in $\mathrm{pH}$ for averages of the nine barrels over the triplicates treatments. 
Biogeosciences Discuss., https://doi.org/10.5194/bg-2017-453

Manuscript under review for journal Biogeosciences

Discussion started: 2 November 2017

(c) Author(s) 2017. CC BY 4.0 License.

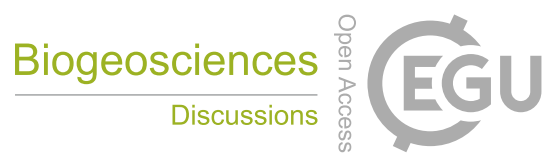

(c) (i)
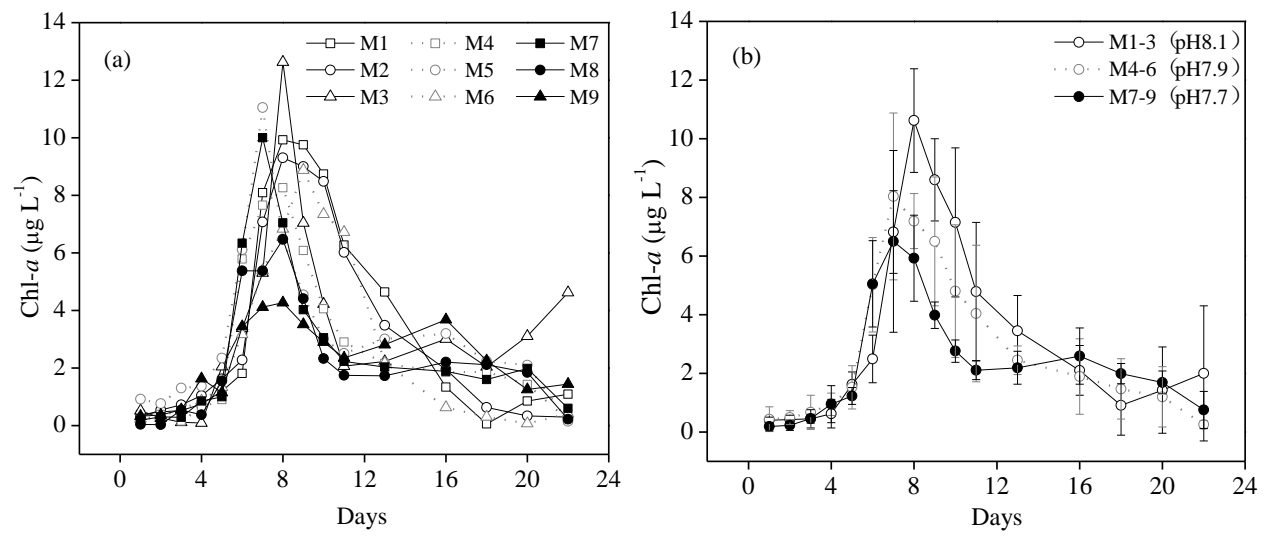

3

4 Figure 2. Temporal changes in the Chl- $a$ concentrations $\left(\mu \mathrm{g} \mathrm{L}^{-1}\right)$ for (a) each of the nine barrels and (b) averages over the

5 triplicates treatments. 
Biogeosciences Discuss., https://doi.org/10.5194/bg-2017-453

Manuscript under review for journal Biogeosciences

Discussion started: 2 November 2017

(c) Author(s) 2017. CC BY 4.0 License.

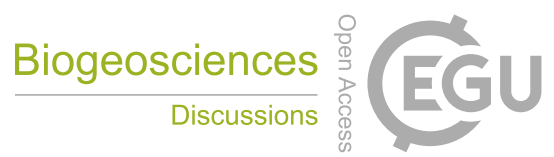

(c) (i)
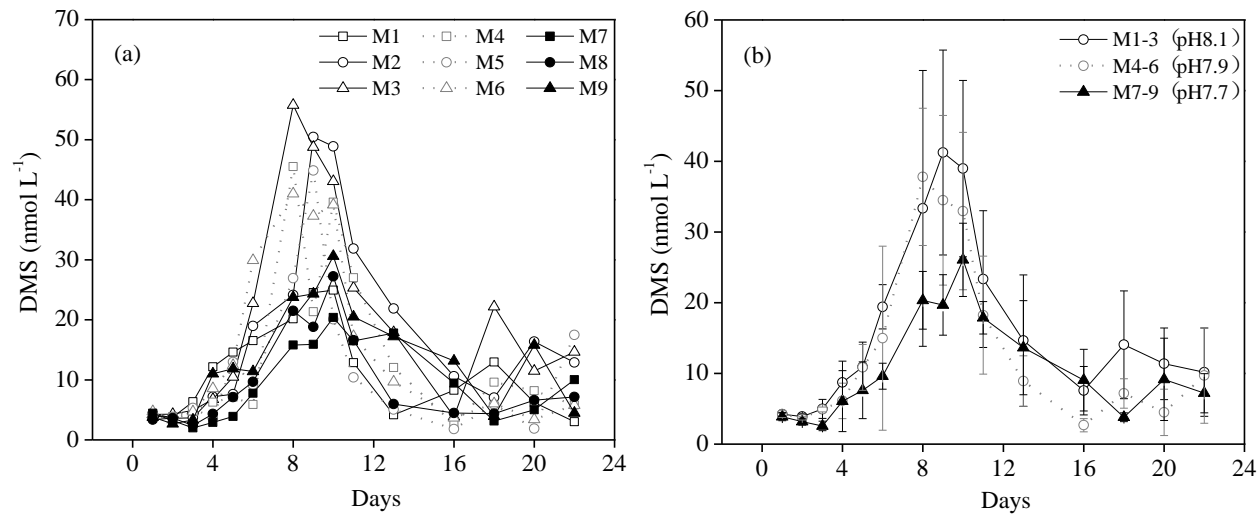

Figure 3. Temporal changes in the DMS concentrations $\left(\mathrm{nmol} \mathrm{L}{ }^{-1}\right.$ ) for (a) each of the nine barrels and (b) averages over the

triplicates treatments. 
Biogeosciences Discuss., https://doi.org/10.5194/bg-2017-453

Manuscript under review for journal Biogeosciences

Discussion started: 2 November 2017

(c) Author(s) 2017. CC BY 4.0 License.
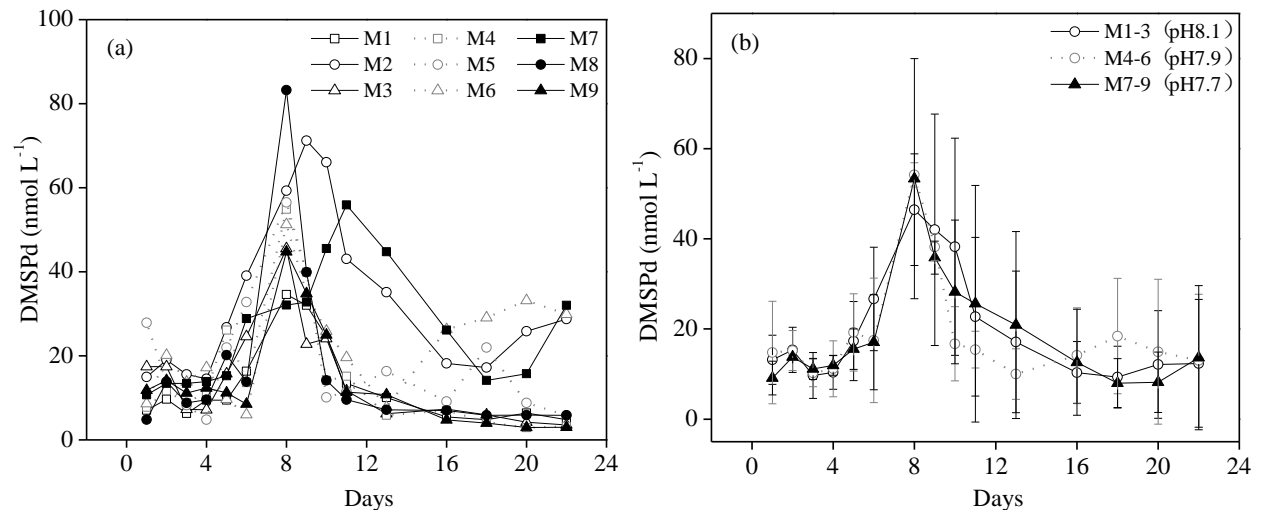

9
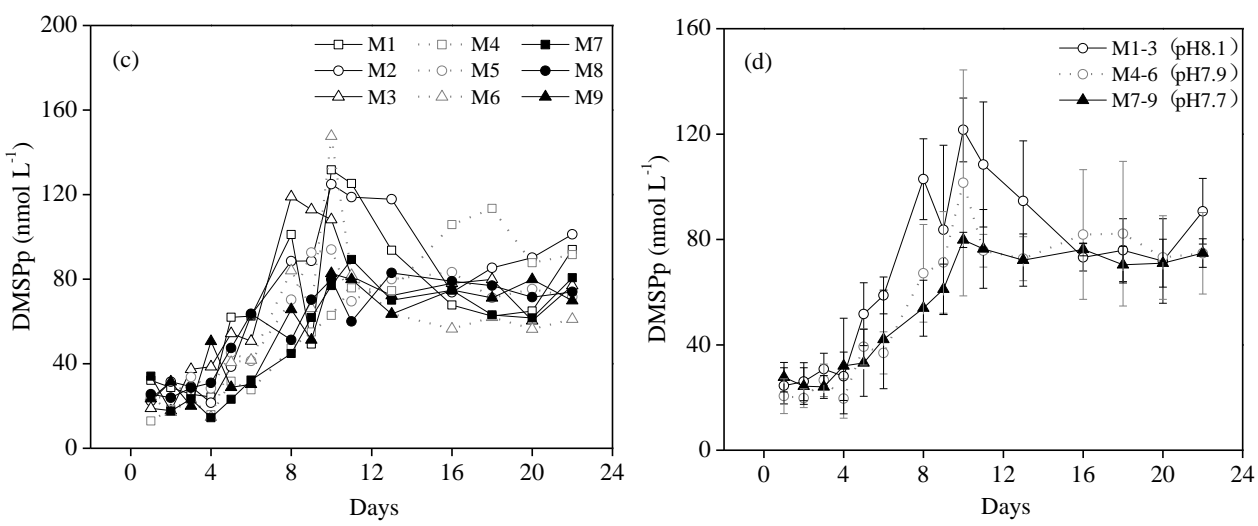

Figure 4. Temporal changes in the DMSPd and DMSPp concentrations $\left(n \mathrm{nmol} \mathrm{L}^{-1}\right)$ for $(\mathrm{a}, \mathrm{c})$ each of the nine barrels and $(b, d)$ 
Biogeosciences Discuss., https://doi.org/10.5194/bg-2017-453

Manuscript under review for journal Biogeosciences

Discussion started: 2 November 2017

(c) Author(s) 2017. CC BY 4.0 License.
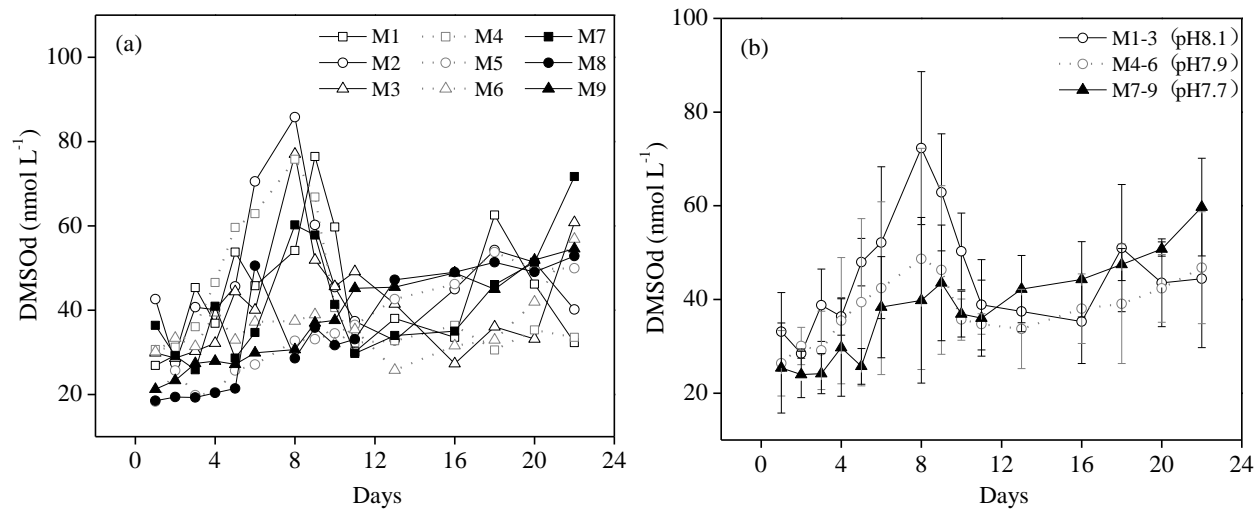

13
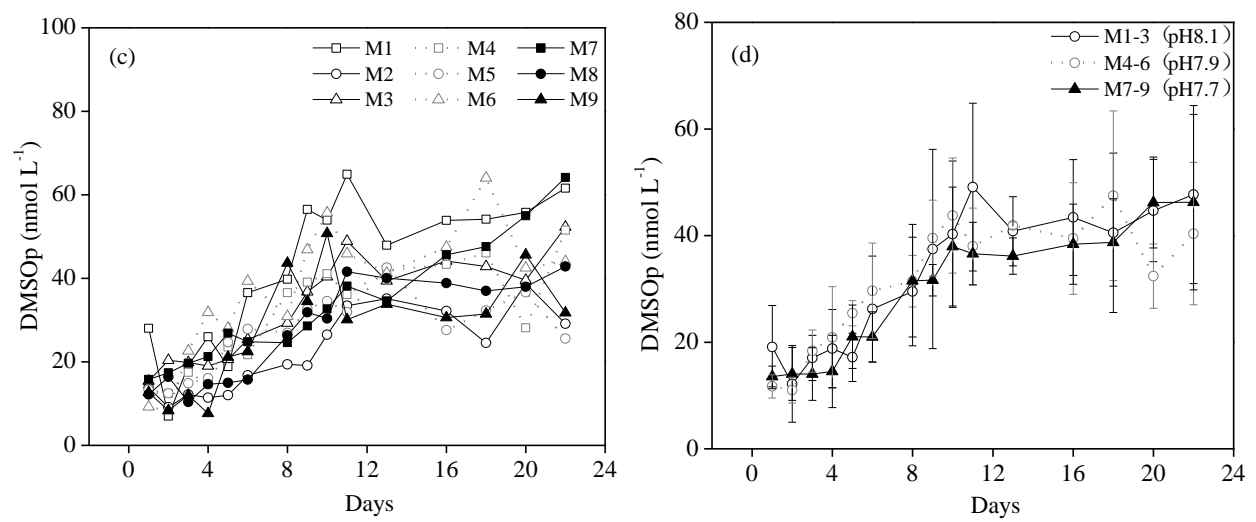

Figure 5. Temporal changes in the DMSOd and DMSOp concentrations $\left(\mathrm{nmol} \mathrm{L}^{-1}\right)$ for $(\mathrm{a}, \mathrm{c})$ each of the nine barrels and $(\mathrm{b}$, 
Biogeosciences Discuss., https://doi.org/10.5194/bg-2017-453

Manuscript under review for journal Biogeosciences

Discussion started: 2 November 2017

(c) Author(s) 2017. CC BY 4.0 License.

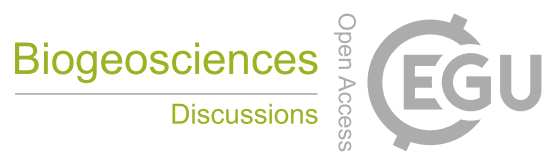

(c) (i)

17

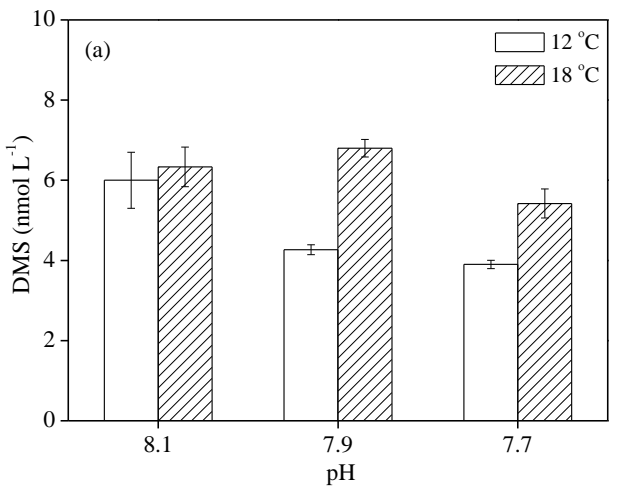

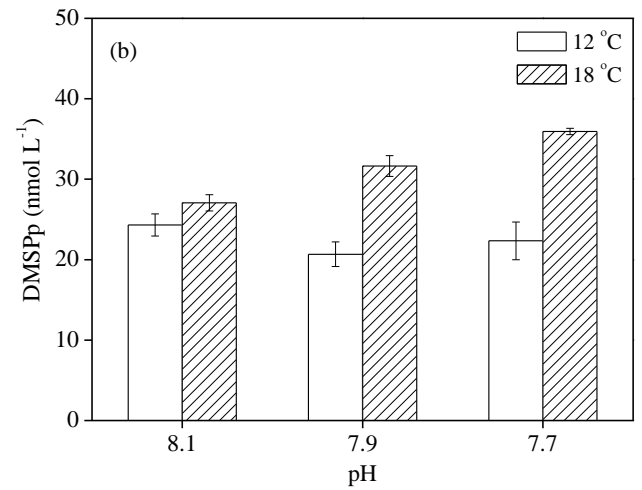

18 Figure 6. Average values of (a) DMS and (b) DMSPp concentrations in the cross experiment of OA and temperature, with

19 three replicate incubation samples per treatment. 
Biogeosciences Discuss., https://doi.org/10.5194/bg-2017-453

Manuscript under review for journal Biogeosciences

Discussion started: 2 November 2017

(c) Author(s) 2017. CC BY 4.0 License.

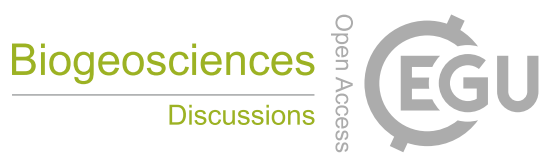

(c) (1)
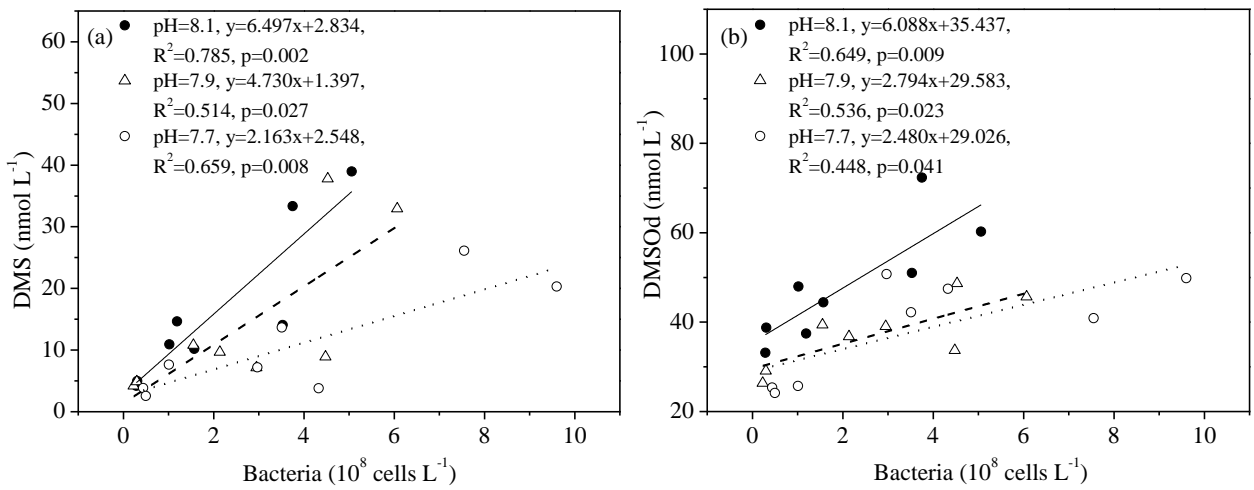

21

Figure 7. Relationships between bacterial abundance, (a) DMS and (b) DMSOd concentrations in the LC (pH 8.1, filled

22

circle, solid lines), $\mathrm{MC}(\mathrm{pH} 7.9$, empty triangle, dash lines) and $\mathrm{HC}(\mathrm{pH} 7.7$, empty circular, dotted lines) treatments during

23 the experiment. 
Biogeosciences Discuss., https://doi.org/10.5194/bg-2017-453

Manuscript under review for journal Biogeosciences

Discussion started: 2 November 2017

(c) Author(s) 2017. CC BY 4.0 License.

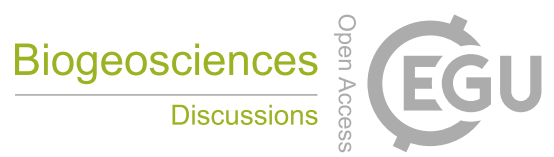

\section{(c) (1)}
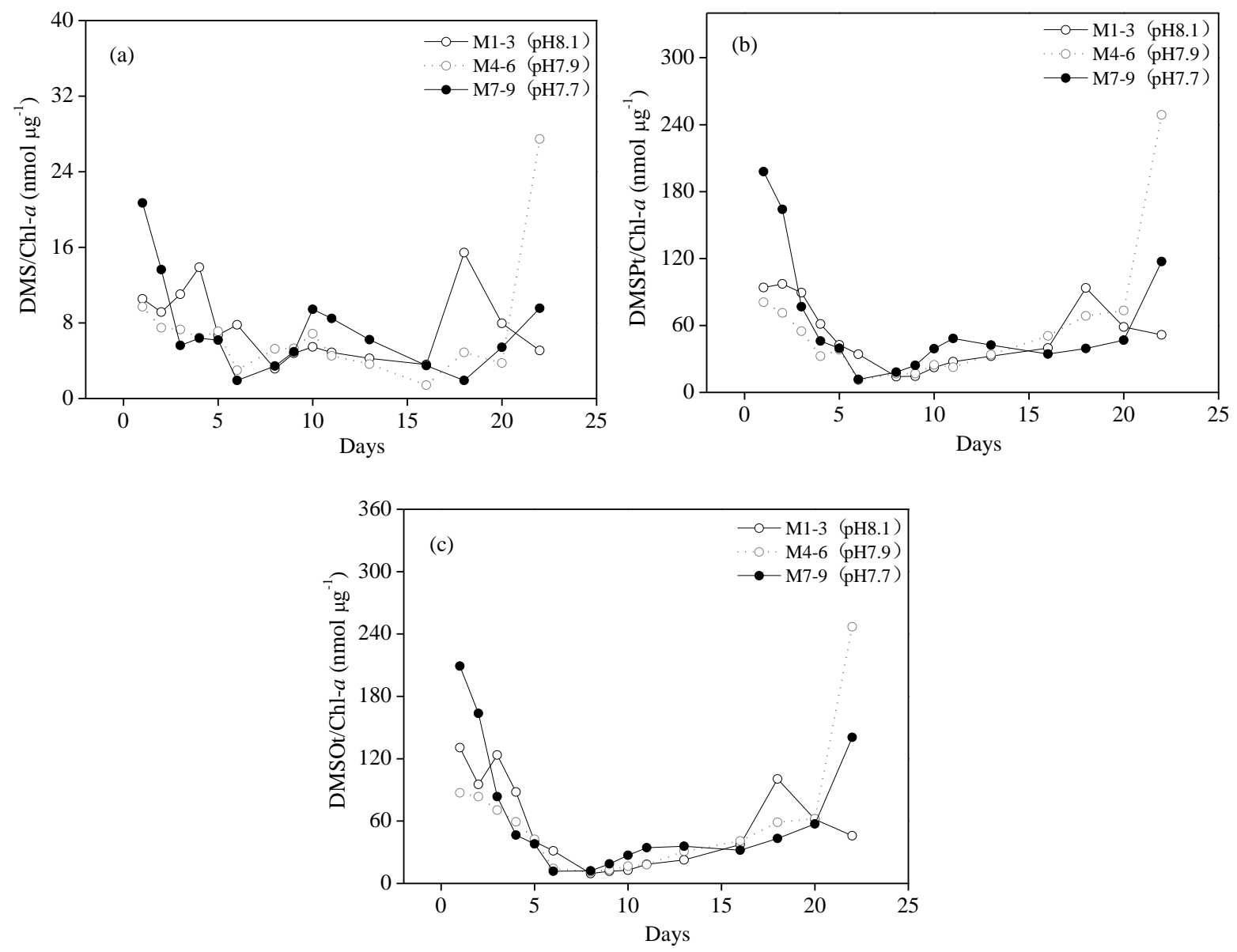

Figure 8. Mean ratios of (a) DMS/Chl- $a$, (b) DMSPt/Chl- $a$, (c) DMSOt/Chl- $a$ for the LC, MC and HC treatments. 
Biogeosciences Discuss., https://doi.org/10.5194/bg-2017-453

Manuscript under review for journal Biogeosciences

Discussion started: 2 November 2017

(c) Author(s) 2017. CC BY 4.0 License.

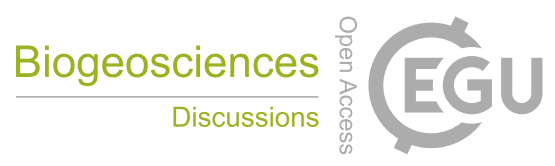

(c) (i)

Table 1. Preliminary carbonate parameters of three treatments during the incubation experiment.

\begin{tabular}{lccccc}
\hline & $\mathrm{pH}$ & $\mathrm{DIC}\left(\mu \mathrm{mol} \mathrm{kg}{ }^{-1}\right)$ & $p \mathrm{CO}_{2}(\mu \mathrm{atm})$ & $\mathrm{HCO}_{3}{ }^{-1}\left(\mu \mathrm{mol} \mathrm{kg}^{-1}\right)$ & $\mathrm{CO}_{3}{ }^{2-}\left(\mu \mathrm{mol} \mathrm{kg}^{-1}\right)$ \\
\hline M1-3 & 8.1 & 2271 & 389.2 & 2087.2 & 168.0 \\
M4-6 & 7.9 & 2263 & 635.9 & 2130.0 & 107.1 \\
M7-9 & 7.7 & 2274 & 1040.7 & 2164.0 & 67.5
\end{tabular}

5 
Biogeosciences Discuss., https://doi.org/10.5194/bg-2017-453

Manuscript under review for journal Biogeosciences

Discussion started: 2 November 2017

(c) Author(s) 2017. CC BY 4.0 License.

treatments over the entire experiment.

\begin{tabular}{|c|c|c|c|c|}
\hline \multirow{2}{*}{ Treatments ( $\mathrm{pH} \pm$ s.d.) } & \multicolumn{4}{|c|}{ Sample concentrations } \\
\hline & Sample & Minimum & Maximum & Mean \pm s.d. \\
\hline$\overline{\mathrm{M} 1-3}$ & Chl- $a\left(\mu \mathrm{g} \mathrm{L}^{-1}\right)$ & 0.06 & 12.6 & $3.14 \pm 3.22$ \\
\hline \multirow[t]{6}{*}{$(\mathrm{pH}=8.11 \pm 0.017)$} & Bacterial abundance $\left(10^{8}\right.$ cell $\left.\mathrm{L}^{-1}\right)$ & 0.29 & 5.06 & $2.09 \pm 1.78$ \\
\hline & DMS $\left(\mathrm{nmol} \mathrm{L}^{-1}\right)$ & 3.03 & 55.8 & $16.5 \pm 12.4$ \\
\hline & DMSPd (nmol L-1) & 3.54 & 71.2 & $20.2 \pm 12.5$ \\
\hline & $\operatorname{DMSPp}\left(\mathrm{nmol} \mathrm{L}^{-1}\right)$ & 17.9 & 132 & $69.5 \pm 31.9$ \\
\hline & DMSOd (nmol L'-1) & 26.9 & 85.8 & $44.9 \pm 11.7$ \\
\hline & DMSOp (nmol L-1) & 6.99 & 64.9 & $32.3 \pm 12.8$ \\
\hline M4-6 & Chl- $a\left(\mu \mathrm{g} \mathrm{L}^{-1}\right)$ & 0.08 & 11.1 & $2.60 \pm 2.31$ \\
\hline \multirow[t]{6}{*}{$(\mathrm{pH}=7.90 \pm 0.022)$} & Bacterial abundance $\left(10^{8}\right.$ cell $\left.\mathrm{L}^{-1}\right)$ & 0.23 & 6.07 & $2.78 \pm 2.12$ \\
\hline & $\operatorname{DMS}\left(\mathrm{nmol} \mathrm{L}^{-1}\right)$ & 1.79 & 45.5 & $13.4 \pm 12.0$ \\
\hline & DMSPd $\left(\mathrm{nmol} \mathrm{L}^{-1}\right)$ & 2.88 & 56.5 & $18.9 \pm 11.8$ \\
\hline & DMSPp $\left(\mathrm{nmol} \mathrm{L}^{-1}\right)$ & 12.9 & 148 & $57.5 \pm 27.3$ \\
\hline & DMSOd $\left(\mathrm{nmol} \mathrm{L}^{-1}\right)$ & 18.3 & 75.8 & $37.9 \pm 6.64$ \\
\hline & DMSOp (nmol L-1) & 8.24 & 64.0 & $31.4 \pm 11.6$ \\
\hline M7-9 & Chl- $a\left(\mu \mathrm{g} \mathrm{L}^{-1}\right)$ & 0.03 & 10.0 & $2.14 \pm 1.72$ \\
\hline \multirow[t]{6}{*}{$(\mathrm{pH}=7.72 \pm 0.029)$} & Bacterial abundance $\left(10^{8}\right.$ cell $\left.\mathrm{L}^{-1}\right)$ & 0.44 & 9.60 & $3.74 \pm 3.35$ \\
\hline & $\operatorname{DMS}\left(\mathrm{nmol} \mathrm{L}^{-1}\right)$ & 1.98 & 30.6 & $10.7 \pm 7.25$ \\
\hline & DMSPd (nmol L-1) & 2.93 & 83.2 & $19.0 \pm 12.4$ \\
\hline & DMSPp $\left(\mathrm{nmol} \mathrm{L}^{-1}\right)$ & 14.4 & 89.3 & $54.6 \pm 21.7$ \\
\hline & DMSOd (nmol L-1) & 18.5 & 71.7 & $37.9 \pm 10.7$ \\
\hline & DMSOp (nmol L'-1) & 7.67 & 64.2 & $29.4 \pm 11.9$ \\
\hline
\end{tabular}


Biogeosciences Discuss., https://doi.org/10.5194/bg-2017-453

Manuscript under review for journal Biogeosciences

Discussion started: 2 November 2017

(c) Author(s) 2017. CC BY 4.0 License.

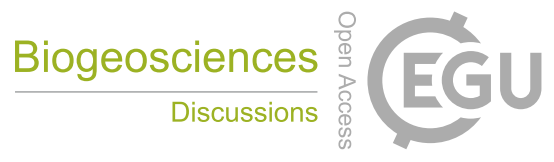

(c) (1)

10 Table 3. DMS photolysis rate constants and turnover time in the cross experiment of OA and light, with three replicate

11 incubation samples per treatment.

\begin{tabular}{ccccccccc}
\hline $\mathrm{pH}$ & $\begin{array}{c}K_{\text {natural light }} \\
\left(\mathrm{d}^{-1}\right)\end{array}$ & $\begin{array}{c}\tau_{\text {photo }}(\mathrm{d}) \\
\end{array}$ & $\begin{array}{c}K_{\text {UVB }} \\
\left(\mathrm{d}^{-1}\right)\end{array}$ & $\begin{array}{c}\text { UVB } \\
\text { contributions }\end{array}$ & $\begin{array}{c}K_{\text {UVA }} \\
\left(\mathrm{d}^{-1}\right)\end{array}$ & $\begin{array}{c}\text { UVA } \\
\text { contributions }\end{array}$ & $\begin{array}{c}K_{\text {visible light }} \\
\left(\mathrm{d}^{-1}\right)\end{array}$ & $\begin{array}{c}\text { Visible light } \\
\text { contributions }\end{array}$ \\
\hline 8.1 & 4.02 & 1.19 & 1.13 & $28.0 \%$ & 2.37 & $59.1 \%$ & 0.52 & $12.9 \%$ \\
7.9 & 5.19 & 0.92 & 3.20 & $61.7 \%$ & 1.53 & $29.5 \%$ & 0.46 & $8.80 \%$ \\
7.7 & 6.32 & 0.76 & 4.73 & $74.9 \%$ & 1.35 & $21.3 \%$ & 0.24 & $3.83 \%$ \\
Average & 5.18 & 0.96 & 3.02 & $55.0 \%$ & 1.75 & $37.0 \%$ & 0.41 & $9.00 \%$ \\
\hline
\end{tabular}

12

13 
Biogeosciences Discuss., https://doi.org/10.5194/bg-2017-453

Manuscript under review for journal Biogeosciences

Discussion started: 2 November 2017

(c) Author(s) 2017. CC BY 4.0 License.

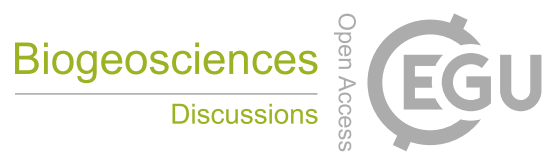

(c) (1)

14 Table 4. Pearson's correlation coefficient and associated significance level for mean dimethylated sulfur compounds and

15 Chl- $a$ concentrations under three different $\mathrm{CO}_{2}$ treatments.

\begin{tabular}{|c|c|c|c|c|c|c|}
\hline & Chl- $a$ & DMS & DMSPd & DMSPp & DMSOd & DMSOp \\
\hline \multicolumn{7}{|c|}{$\overline{\mathrm{LC}}(\mathrm{pH}=8.1)$} \\
\hline Chl- $a$ & 1 & & & & & \\
\hline DMS & $.925^{* *}$ & 1 & & & & \\
\hline DMSPd & $.946 * *$ & $.923 * *$ & 1 & & & \\
\hline DMSPp & $.724 * *$ & $.732 * *$ & $.570^{*}$ & 1 & & \\
\hline DMSOd & $.791^{*}$ & $.778 * *$ & $.789 * *$ & $.522^{*}$ & 1 & \\
\hline DMSOp & .334 & .380 & .119 & $.816^{* *}$ & .200 & 1 \\
\hline \multicolumn{7}{|c|}{$\mathrm{MC}(\mathrm{pH}=7.9)$} \\
\hline Chl- $a$ & 1 & & & & & \\
\hline DMS & $.913 * *$ & 1 & & & & \\
\hline DMSPd & $.769 * *$ & $.784 * *$ & 1 & & & \\
\hline DMSPp & .409 & .445 & .198 & 1 & & \\
\hline DMSOd & $.541^{*}$ & $.533^{*}$ & $.626^{*}$ & .481 & 1 & \\
\hline DMSOp & .400 & .382 & .137 & $.929 * *$ & $.545^{*}$ & 1 \\
\hline \multicolumn{7}{|c|}{$\mathrm{HC}(\mathrm{pH}=7.7)$} \\
\hline Chl- $a$ & 1 & & & & & \\
\hline DMS & $.657 * *$ & 1 & & & & \\
\hline DMSPd & $.756 * *$ & $.806 * *$ & 1 & & & \\
\hline DMSPp & .323 & $.570^{*}$ & .218 & 1 & & \\
\hline DMSOd & .308 & .238 & .080 & $.807 * *$ & 1 & \\
\hline DMSOp & .265 & .439 & .157 & $.951 * *$ & $.896 * *$ & 1 \\
\hline
\end{tabular}

$16 * *$. Correlation is significant at the 0.01 level (2-tailed).

17 *. Correlation is significant at the 0.05 level (2-tailed).

18 